\title{
Relational Contracts of Adhesion
}

\author{
David A. Hoffman†
}

Not all digital fine print exculpates liability: some exhorts users to perform before the consumer relationship has soured. We promise to choose strong passwords (and hold them private); to behave civilly on social networks; to refrain from streaming shows and sports; and to avoid reverse-engineering code (or, worse, deploying deadly bots). In short, consumers are apparently regulated by digital fine print, though it's universally assumed that we don't read it and, even if we did, that we'll never be sued for failing to perform.

On reflection, this ordinary phenomenon is perplexing. Why would firms persist in deploying uncommunicative behavioral spurs? The conventional answer is that fine print acts as an option, drafted by dull, guild-captured lawyers. Through investigation of several sharing-economy firms and discussions with a variety of lawyers in this space, I show that this account is incomplete. Indeed, I identify and explore examples of fine print from sharing-economy firms that seem intended to actually communicate with and manage users.

The drafters of these clauses claim that they successfully deployed the fine print by trading on their brands and identities and by giving up on certain exculpatory defenses. I argue that the resulting terms may point toward a new form of relational contracting, taking on attributes of both mass adhesion contracts and longer-term deals.

INTRODUCTION 1396

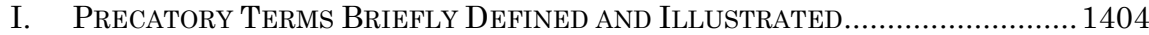

II. Standard Accounts for the Persistence of Precatory Fine

PRINT...

A. Commercial Terms and Contract Behavior .................................... 1408

B. The Standard Account: The Option Value of Fine Print ................. 1412

C. Legal Market Failure

$\dagger$ Professor of Law, University of Pennsylvania Law School. I would like to thank the individuals who agreed to be interviewed for this article: Hissan Bajwa, Michal Rosenn, Bonnie Broeren, Rob Chesnut, Eric Goldman, Jay Monahan, Ari Shahdadi, Curtis Anderson, Ed Ferguson, Michael Cheah, Hansen Tong, and Miranda Lerner. Katherine Schloss Ackerman (Penn '17), Elyssa Eisenberg (Penn '18), and Michelle Kao (Penn '18) provided research assistance. Tom Baker, Shyam Balganesh, Danielle Citron, Zev Eigen, Meirav Furth-Matzkin, Eric Goldman, Ethan Leib, Sophia Lee, Greg Klass, Florencia Marotta-Wurgler, Melanie McMenamin, Lior Strahilevitz, Rick Swedloff, Michael Risch, Tess Wilkinson-Ryan, David Wishnick, and participants at faculty workshops at the University of Pennsylvania, Boston University, UC Hastings, Villanova University, University of Chicago, and the Second Empirical Contracts Working Group provided useful feedback. 
III. Communicating Through Contracts.................................................... 1421

A. Tumblr: Because They Cared........................................................... 1423

B. Kickstarter: Reflecting Its Values ........................................... 1427

C. Etsy: Handcrafted Terms .......................................................... 1432

D. Airbnb: Solving a Public Relations Crisis ........................................ 1437

E. Bumble: We're Not Tinder ............................................................ 1440

IV. From Options to Relational Contracts of AdHesion ........................ 1441

A. Branding and Mass-Market Contracts........................................... 1442

B. The Costs and Consequences of Innovations .................................. 1447

C. Relational Contracts of Adhesion .................................................... 1452

D. The Future of Contract Regulation (and Regulation by Contract)

\section{INTRODUCTION}

Consumer contract theory is myopically focused on the unread fine print. ${ }^{1}$ Because consumers don't read their contracts, ${ }^{2}$ firms can make "hidden" terms worse without lowering prices. ${ }^{3}$ At best, the platonic consumer contract is read by exactly two people, both lawyers: the drafter curating it from the carcasses of past agreements $^{4}$ and the plaintiff's counsel, immediately before explaining to an injured client that her case is hopeless. ${ }^{5}$ Yet perversely, when judges and juries evaluate terms ex post, they

\footnotetext{
1 For the modern classic treatment, see Ian Ayres and Alan Schwartz, The NoReading Problem in Consumer Contract Law, 66 Stan L Rev 545, 558-60 (2014).

2 See, for example, Yannis Bakos, Florencia Marotta-Wurgler, and David R. Trossen, Does Anyone Read the Fine Print? Consumer Attention to Standard-Form Contracts, 43 J Legal Stud 1, 19 (2014) (finding that, in a study of visits to software retailers' websites, consumers accessed end-user license agreements (EULAs) 0.08 percent of the time).

3 See Florencia Marotta-Wurgler, Does Contract Disclosure Matter?, 168 J Inst \& Theoretical Econ 94, 113-14 (2012) (finding that exposure to a one-sided term in a software license agreement has no effect on the likelihood of purchasing the product in question); Daniel Schwarcz, Reevaluating Standardized Insurance Policies, 78 U Chi L Rev 1263, 1315-17 (2011) (explaining the concern that insurance companies "exploit[ ] consumer ignorance to ratchet back coverage" without corresponding discounts).

4 See Florencia Marotta-Wurgler and Robert Taylor, Set in Stone? Change and Innovation in Consumer Standard-Form Contracts, 88 NYU L Rev 240, 247 (2013) (discussing the process of consumer contract creation, through which in-house counsel is best positioned to revise boilerplate language and language taken from other firms).

5 In reality, many consumers complain to firms without the benefit of counsel (because the stakes of the dispute are low). In such instances, the corporation may create its own idiosyncratic dispute resolution system. See Rory Van Loo, The Corporation as Courthouse, 33 Yale J Reg 547, 558-66 (2016) (explaining predominant aspects of corporate dispute resolution systems); Lisa Bernstein and Hagay Volvovsky, Not What You Wanted to Know: The Real Deal and the Paper Deal in Consumer Contracts-Comment on the Work of Florencia Marotta-Wurgler, 11 Jerusalem Rev Legal Stud 128, 130-32 (2015) (explaining that companies' actual practices for resolving consumer complaints can differ
} 
blame consumers for failing to exercise care and hold them to their deals. ${ }^{6}$ The result is a legitimacy crisis that generates much modern contracts scholarship. ${ }^{7}$

But even as this account has settled into the new, cynical, conventional wisdom, a new form is arising. The modern consumer experience now includes participation in the creation of goods and services. ${ }^{8}$ Firms enlist consumers in building intellectual property. They ask us to review goods and services, and use

from their formal policies in ways that have the effect of avoiding litigation); Jason Scott Johnston, The Return of Bargain: An Economic Theory of How Standard-Form Contracts Enable Cooperative Negotiation between Businesses and Consumers, 104 Mich L Rev 857, 865 (2006) (highlighting corporations' use of employee discretion in departing from formal contractual terms).

6 See Tess Wilkinson-Ryan, A Psychological Account of Consent to Fine Print, 99 Iowa L Rev 1745, 1764-65 (2014) (presenting results of an experiment in which subjects often blamed consumers for failing to read bad terms).

7 See, for example, Tess Wilkinson-Ryan, The Perverse Consequences of Disclosing Standard Terms, 103 Cornell L Rev 117, 124-26 (2017) (discussing various doctrinal approaches to the no-reading problem); David A. Hoffman, From Promise to Form: How Contracting Online Changes Consumers, 91 NYU L Rev 1595, 1597 (2016) (characterizing digital contracts as sterile and frequently the subject of satire); Nathan B. Oman, The Dignity of Commerce: Markets and the Moral Foundations of Contract Law 134-59 (Chicago 2016) (considering arguments regarding consent for consumer boilerplate and concluding that policing on substance, not process, is desirable); Omri Ben-Shahar, Book Review, Regulating through Boilerplate: An Apologia, 112 Mich L Rev 883, 900-01 (2014) (highlighting distributive problems with "protective policies" meant to replace boilerplate contracts); Oren Bar-Gill and Ryan Bubb, Credit Card Pricing: The CARD Act and Beyond, 97 Cornell L Rev 967, 1003 (2012) (advocating for new and better disclosure regimes, including aggregated fee information, which the consumer can better assess); Zev J. Eigen, Experimental Evidence of the Relationship between Reading the Fine Print and Performance of Form-Contract Terms, 168 J Inst \& Theoretical Econ 124, 134 (2012) (citing the "low stakes of the exchange" as one of the "typical" explanations of low readership); Victoria C. Plaut and Robert P. Bartlett III, Blind Consent? A Social Psychological Investigation of Non-Readership of Click-Through Agreements, 36 L \& Hum Behav 293, 305-06 (2012) (exploring the relationship between lack of readership and assent to contractual provisions); Omri Ben-Shahar and Carl E. Schneider, The Failure of Mandated Disclosure, 159 U Pa L Rev 647, 704-11 (2011) (exploring the problem of no-reading); Oren Bar-Gill and Kevin Davis, Empty Promises, 84 S Cal L Rev 1, 19-26 (2010) (articulating problems caused by unilateral modification clauses); Oren Bar-Gill, Seduction by Plastic, $98 \mathrm{Nw}$ U L Rev 1373, 1417-20 (2004) (advocating for consumer-friendly modifications to credit card fee disclosure policies).

8 See Gillian K. Hadfield, Rules for a Flat World: Why Humans Invented Law and How to Reinvent It for a Complex Global Economy 154 (Oxford 2017) (discussing the complexity of monitoring copying of digital information, such as music and videos, when the "boundary between who is a supplier and who is a consumer dissolves," and how relaxed restrictions on copying can enable consumers to become creators). The question of labeling users of sharing economy sites as "consumers" is intensely contested. See Ryan Calo and Alex Rosenblat, The Taking Economy: Uber, Information, and Power, 117 Colum L Rev 1623,1660 (2017) (arguing that labeling drivers as consumers is part of Uber's strategy of exploiting them). 
those reviews in driving future sales. Platforms match users with each other, seeking to disintermediate established transportation and distribution networks. ${ }^{9}$ Overall, consumer agency, not passivity, is the rhetoric, if not the reality, of the "sharing economy." 10

The evolution of consumers into participants has implications for contract law. Indeed, it is contract that makes the transmutation possible. Our economy is now shaped in part by the success and failure of terms that don't just exculpate firms from liability, but also express the drafters' hopes about how users will behave. In part through the fine print, firms may aim to influence consumers' performance before the parties' interests become adverse. That is, consumer contracts can't be described as merely containing unfair and defensive hidden terms: they also contain a set of instructions, what I call "precatory fine print." 11

Precatory fine print is distinctive from its aversive and defensive cousin. Unlike a clause defeating class action practice or one disclaiming consequential damages, precatory terms are not primarily intended to have legal effect. Indeed, in the rare instances that firms seek to enforce clauses in the courts of law, they get into trouble. ${ }^{12}$ Consider the example of streaming media online. Firms often use boilerplate to try to extend their intellectual property rights-for example, by prohibiting consumers from asserting fair use under circumstances in which the prevailing law

9 In this Article, I generally use "consumer" to refer to users of platform economy sites, though those individuals may be either buyers or sellers. See Hadfield, Rules for a Flat World at 154 (cited in note 8).

10 The literature on the sharing economy is vast. For a useful recent survey, see Calo and Rosenblat, 117 Colum L Rev at 1641-45 (cited in note 8) (describing the promise of the sharing economy).

11 The use of the term "precatory" to describe consumer contracts' terms of use is novel in published literature, though I did hear Professor Pamela Samuelson use it in a conference I attended.

12 Apart from the no-review example I give in this Article, the widely mocked, and largely unsuccessful, attempt to use precatory terms of use as the basis for violation of the Computer Fraud and Abuse Act, Pub L No 99-474, 100 Stat 1213, codified at 18 USC § 1001 et seq, provides both a cautionary tale and evidence of the point. As the leading commentator on the statute argued, the prosecution was problematic in part because "Internet users routinely click through such agreements on the assumption that they are legal mumbo jumbo that don't impact what users are allowed to do." Orin S. Kerr, Vagueness Challenges to the Computer Fraud and Abuse Act, 94 Minn L Rev 1561, 1582 (2010). 
would permit it. ${ }^{13}$ Though controversial among academics, these clauses are rarely, if ever, enforced against consumers. ${ }^{14}$

A different way to think about these clauses is behavioral: content providers hope to influence how their users interact with their intellectual property. ${ }^{15}$ Take a single example: HBO Go. For those who, for whatever reason, are not Game of Thrones fans and consequently don't subscribe, ${ }^{16}$ HBO Go enables users to stream the channel's programs to their screen, untethered to their cable connection. Obviously, HBO is concerned that users might expand the scope of the license in various ways. It expresses that concern in a contract term, buried in a 7,100-plus-word terms of use. The seventh section is titled "RESTRICTIONS ON USE OF MATERIALS." 17 To save space, I've cut out some words. Still, the mind reels:

(a) You may not copy, reproduce, distribute, transfer, sell, license, publish, enter into a database, display, perform publicly, modify, create derivative works, upload, edit, post, link to, frame, transmit, rent, lease, lend or sublicense or in any way exploit any part of the Services, or attempt to interfere with the operation of the Services in any way, except that you may access and display material and all other Content displayed on the Services for non-commercial, personal, entertainment use for a limited time only as strictly authorized

13 See Guy A. Rub, Copyright Survives: Rethinking the Copyright-Contract Conflict, 103 Va L Rev 1141, 1198, 1203 (2017) (describing common "super-copyright" contractual provisions that preclude fair use of copyrighted material).

14 See id at 1197-1204 (analyzing 279 cases in which contract claims were asserted and finding no consumer defendants). For discussion of these controversial clauses, see Guy A. Rub, Contracting around Copyright: The Uneasy Case for Unbundling of Rights in Creative Works, 78 U Chi L Rev 257, 277 (2011) (discussing possible costs of fair userestricting contracts to "transformative users"); Mark A. Lemley, Terms of Use, $91 \mathrm{Minn}$ L Rev 459 (2006); Julie E. Cohen, Copyright and the Perfect Curve, 53 Vand L Rev 1799, 1805 (2000) (describing a "growing body of copyright scholarship" advocating "the freedom to contract around copyright limitations such as ... the fair use doctrine"); David Nimmer, Elliot Brown, and Gary N. Frischling, The Metamorphosis of Contract into Expand, 87 Cal L Rev 17, 74 (1999) (arguing that license provisions that impermissibly restrict fair use rights should be invalid).

15 See Zev J. Eigen, An Experimental Test of the Effectiveness of Terms \& Conditions *3 (Northwestern Law \& Economics Research Paper No 13-32), archived at http://perma.cc/7D9Y-ZB7K.

16 This is a mistake, even if George R.R. Martin will never, ever finish writing the series. See Hoffman, 91 NYU L Rev at 1599 n 15 (cited in note 7) (explaining the problem of fantasy authors promising too much).

17 HBO Go Terms (HBO Go, Apr 3, 2012), archived at http://perma.cc/NUR5 -DCYX?type=image. 
herein. You may not use any data mining, robots, or similar data gathering and extraction tools on the Services or on any portion of the Service, or frame any portion of the Service. Without limiting the generality of the foregoing, you may not distribute any part of the Services over any network, including a local area network, nor sell or offer it for sale. You may not assign, sublicense, pledge or transfer any of your rights or obligations under this Agreement to any person or entity without HBO's prior written consent which may be withheld in HBO's sole discretion (and any such purposed assignment, pledge or transfer without such prior written consent shall be void ab initio). In addition, these files may not be used to construct any kind of database. ... Using any material on any other Service or networked computer environment is prohibited. Also prohibited are: decompiling, reverse engineering, disassembling, or otherwise reducing the code used in any software or digital rights management feature on the Services into a readable form in order to examine the construction of such software and/or to copy or create other products based (in whole or in part) on such software or any feature of the Services, or intercepting and/or recording network communications transmitted between the Services and HBO.... (c) HBO and its partners and affiliates may suspend or terminate your subscription and access to the Services immediately if HBO reasonably determines that you are in violation of this Agreement or receives information that you no longer meet the Eligibility Criteria. In such event, you must cease all use of the Services. The suspension or termination of your subscription is in addition to, and not in lieu of, any rights and remedies available to $\mathrm{HBO}$, its partners and affiliates under this Agreement or under applicable laws. ${ }^{18}$

Let's stipulate that the only nonlawyer in the history of the world who read that entire "paragraph" was the poor $2 \mathrm{~L}$ student who checked it for accuracy.19 If you feel shamed by the last sentence and resolve to go back and really read it this time, you would find that HBO's customers promise to do all sorts of things they will not be sued for failing to do, including watching Cersei

18 Id.

19 Sorry not sorry. 
Lannister burn her enemies over a local area network. ${ }^{20}$ Yet it is impossible to imagine that any ordinary consumer would be tempted to read this exhortation or, having read it, change her behavior. ${ }^{21}$ And for a small yet significant class of consumers, these warnings may even encourage unlicensed activity. ${ }^{22}$

What, then, is the point of precatory fine print? When pressed, some argue that it offers firms a sort of option value. It's not as if firms hope to enforce terms either in or out of court. Rather, the terms provide rights to be exercised rarely-that is, when consumers act in highly disruptive ways. ${ }^{23}$ This opportunistic account dominates discussions not just of exculpatory consumer contract clauses but also of precatory ones. In effect, most scholars think of precatory clauses as little more than exculpatory clauses occasionally enforced through demand letters and algorithmic moderators instead of motions to dismiss. Accordingly, precatory fine print is rarely the subject of distinct law review treatments. ${ }^{24}$

20 Admit it, you got bored and stopped reading. And I excised around 100 words from the middle just to make it easier for you.

21 See Jenna Wortham, The Unrepentant Bootlegger (NY Times Sept 27, 2014), online at http://www.nytimes.com/2014/09/28/technology/the-unrepentant-bootlegger.html (visited Mar 31, 2018) (Perma archive unavailable).

22 See Eigen, An Experimental Test at *22-23 (cited in note 15) (finding that terms and conditions induced more cheating than other forms of behavioral modification).

23 See Lucian A. Bebchuk and Richard A. Posner, One-Sided Contracts in Competitive Consumer Markets, 104 Mich L Rev 827, 833-34 (2006) (describing how firms "dependably treat consumers much better than their contracts require them to do" in response to consumer expectations).

24 The best paper in this field is an unpublished experimental piece by Zev Eigen. Eigen, An Experimental Test at *3-7 (cited in note 15) (arguing that firms wrongly use terms and conditions to attempt to reduce digital piracy). Other good related work includes Danielle Keats Citron, Online Engagement on Equal Terms, BU L Rev Online (Oct 19, 2015), archived at http://perma.cc/SVY6-HTFX (showing that Twitter, for instance, has increased the number of demands it makes on consumers over the years); M. Ryan Calo, Against Notice Skepticism in Privacy (and Elsewhere), 87 Notre Dame L Rev 1027, 105758 (2012) (suggesting that the existence of a website privacy policy may influence consumer behavior even if it is not read); Danielle Keats Citron and Helen Norton, Intermediaries and Hate Speech: Fostering Digital Citizenship for Our Information Age, 91 BU L Rev 1435, 1440, 1478-79 (2011) (suggesting that intermediaries can use terms of service to civilize internet behavior); Woodrow Hartzog, Website Design as Contract, 60 Am U L Rev 1635, 1650-53 (2011) (arguing for a design-centered contract law that recognizes that elements of a website's design can constitute a promise); Joshua A.T. Fairfield, Anti-Social Contracts: The Contractual Governance of Virtual Worlds, 53 McGill L J 427, 435-38 (2008) (discussing the use of EULAs to govern virtual worlds); Lee Anne Fennell, Contracting Communities, 2004 U Ill L Rev 829, 884-90 (discussing residential community contracts). There is also a literature on the relationship of criminal sanctions to contract terms, which appears to take the standard line. For example, see Orin S. Kerr, Cybercrime's Scope: Interpreting "Access" and "Authorization" in Computer Misuse 
This option account proves too little. Descriptively, in many industries the value for the "option" would be vanishingly low, as the reputational costs for triggering it would be exceptionally high. ${ }^{25}$ Moreover, even if firms want to preserve their ex post options, why have they done so through a communicative medium that's famously unread? Why haven't they innovated to find ways to both corral their customers ex ante and also preserve their flexibility ex post?

Some have argued that the current look and feel of the fine print is evidence of a market failure resulting from a monopoly: the organized bar. As imperfect-and badly trained-agents, lawyers simply can't solve clients' consumer contracting problems and repeatedly turn to the tools closest at hand. ${ }^{26}$ In other words: the fine print looks the way it does because lawyers have failed to innovate even though innovation would be valuable for their clients. Thus, we will have communicative contracts only in a world in which the gates around the profession are breached, and lawyers can join hands with accountants and engineers to build better forms.

This story is also incomplete. In this Article, I challenge the conventional wisdom by providing examples of mass-market terms that seem to really influence user behavior outside of court. I do so through a series of interview-generated case studies of the user agreements from prominent new-economy firms, including Etsy, Airbnb, Tumblr, and Kickstarter. This is good news: it may suggest a distinct way forward in our understanding of the future of contracting online. Firms can innovate in this space, if they want to, and lawyers can help them do so.

Statutes, 78 NYU L Rev 1596, 1659 (2003) (criticizing regulation by contractual terms of use in part because they are widely known to be unread and unclear).

25 The Recording Industry Association of America, for example, abandoned its campaign to sue users for downloading music after it became a "public-relations disaster." Sarah McBride and Ethan Smith, Music Industry to Abandon Mass Suits (Wall St J, Dec 19, 2008), online at http://www.wsj.com/articles/SB122966038836021137 (visited Mar 31, 2018) (Perma archive unavailable). Even threats to sue can be disastrous. The "Streisand Effect" was a term coined by Mike Masnick in 2005 to explain how attempts to remove information from the internet frequently cause that information to become even more salient. See Mike Masnick, For 10 Years Everyone's Been Using “The Streisand Effect” without Paying; Now I'm Going to Start Issuing Takedowns (TechDirt, Jan 8, 2015), archived at http://perma.cc/4WMX-2VYT.

26 See Hadfield, Rules for a Flat World at 228-37 (cited in note 8) (blaming the bar monopoly for law schools' and lawyers' failure to innovate around terms); Eigen, $A n$ Experimental Test at *3-5 (cited in note 15) (noting lawyers' risk aversion as a driver of the failure to innovate). 
Close inspection of these innovative agreements suggests they might represent a new form of contracting, which I call "relational contracts of adhesion." Unlike firms deploying typical, adhesive, mass-consumer contracts, these new firms actively try to motivate readership. In so doing, they hope to govern ex ante behavior without recourse to court sanctions, do not inevitably seize every advantage, harmonize the look and feel of the terms with their larger brands as an aspect of trade dress, and have seemingly succeeded in creating mass-market forms that have some of the attributes of "real" contracts. They are thus relational.

But unlike traditional relational contracts between firms, these contracts are not negotiated, the parties are at best loosely bound, and the users are both merchants and consumers at the same time. That is, successful precatory terms are neither fish nor fowl: they take on aspects of both the fabled past of individualized contracting and the cynical present of exploitative standard terms. On the whole, my description of relational contracts of adhesion challenges the prevailing account of consumer contracting in the sharing economy, which is typically focused on its dystopian and exploitative aspects. ${ }^{27}$

This Article thus has several goals. First, I want to carve out precatory terms in adhesion contracts as the objects of study. Though consumer contracts have been discussed at length for decades, the degree to which they contain language that purports to persuade rather than compel has been largely ignored by contract theorists. Part I of this Article provides some examples of precatory terms in their fine-print context, and Part II pieces together the standard account for their continued existence. But the standard account is unconvincing. Part III offers a series of case study examples, based on interviews with market players, of precatory terms that seem to be functional in motivating user behavior outside of court. Part IV offers a theory that knits together these case studies and suggests that they illustrate a distinct form of relational contracting. The conditions giving rise to these contracts may suggest the need for different forms of government intervention in the sharing economy.

27 See, for example, Calo and Rosenblat, 117 Colum L Rev at 1660-61 (cited in note 8) (arguing that contracting is a way that firms like Uber exploit their drivers). 


\section{PRECATORY TERMs BRIEFly Defined AND ILLUSTRATED}

To start, I confess to using the word precatory in an idiosyncratic sense. Ordinarily, precatory legal language has no legal effect at all28-for example, a clause in a will expressing the testator's desires about her pet's care. ${ }^{29}$ But some of the fine print I describe is in theory enforceable in court. For the purposes of this Article, I define precatory fine print as language in a massmarket contract that (1) is exceedingly unlikely to be enforced in court; (2) purports to govern the user's conduct outside of the decision to purchase; and (3) introduces terms that the firm would like, all else equal, to see performed.

I have already mentioned that intellectual property contracts are paradigmatic examples of precatory terms. These are both omnipresent and never enforced against consumers. ${ }^{30}$ Perhaps because of that lack of enforcement, there is little evidence that any consumer has been motivated by the terms and conditions of licensed intellectual property to avoid copying. ${ }^{31}$ It's a puzzle. Here is a field in which the firm-side demand to regulate consumersto have them behave differently-is high. However, though the underlying firms are innovative and dynamic players in a rapidly changing market, they have settled on a particularly inane strategy. Each imposes boilerplate prohibitions that are as hard to understand as they are to read from beginning to end.

Other precatory terms purport to control consumer speech, creating a "sort of jurisprudence" for all speech acts on a particular platform. ${ }^{32}$ Indeed, as Professor Jeffrey Rosen has observed, consumer contracts seem to give the employees of digital companies "more power over who gets heard around the globe than any

28 Black's Law Dictionary 1366 (10th ed 2014) (defining "precatory word[s]" as "expressions of requests, desires, or recommendations, as distinguished from commands" and noting that "[g]enerally, precatory words are not recognized as legally enforceable instructions").

29 See Alyssa A. DiRusso, He Says, She Asks: Gender, Language, and the Law of Precatory Words in Wills, 22 Wis Women's L J 1, 16 (2007) (describing precatory language in wills concerning pets).

30 Rub, 103 Va L Rev at 1184-91 (cited in note 13) (discussing the set of doctrinal and practical hurdles to using contracts to enforce anticopying rules).

31 See id at 1198.

32 Marvin Ammori, The "New" New York Times: Free Speech Lawyering in the Age of Google and Twitter, 127 Harv L Rev 2259, 2273 (2014), quoting Somini Sengupta, Twitter Yields to Pressure in Hate Case in France (NY Times, July 12, 2013), online at http://www.nytimes.com/2013/07/13/technology/twitter-yields-to-pressure-in-hate-case-in -france.html (visited Apr 11, 2018) (Perma link unavailable). 
politician or bureaucrat-more power, in fact, than any president or judge." 33

The easiest example to parse is a digital media site that prohibits, using a contract, certain kinds of comments on news stories. Breitbart News, a site that we might not ordinarily associate with civility, enjoins its users with a long list of ways that they may not interact with the webpage, all in boilerplate form. For example, users agree not to:

use the Services in any way that abuses, defames, stalks, annoys, threatens, harasses or violates the rights of privacy, publicity, intellectual property or other legal rights of a person or entity (now or hereafter recognized) or which encourages conduct which would violate any law or give rise to civil or criminal liability or post, publish, transmit, distribute, disseminate or upload any inappropriate, infringing, defamatory, profane, indecent, obscene, lewd, lascivious, filthy, excessively violent or illegal/unlawful material or matters, including, without limitation, information, topics, names or other material;

[provide user content that] degrades others on the basis of gender, race, class, ethnicity, national origin, religion, sexual preference, orientation or identity, disability, or other classification. ${ }^{34}$

A related attempt to control user behavior occurs when firms that sell goods to the public attempt to control their "community's" behavior on the firm's own site. That behavior's locus is typically user reviews. Firms actively monitor and moderate reviews ex post, but they also attempt to shape them ex ante

33 Jeffrey Rosen, This Hate Has Been Removed by the Administrator, New Republic 22 (May 13, 2013). See also Danielle Keats Citron, Extremist Speech, Compelled Conformity, and Censorship Creep, 93 Notre Dame L Rev 1035, 1038 (2018) (describing transnational problems of private speech in TOS enforcement). See also generally Kate Klonick, The New Governors: The People, Rules, and Processes Governing Online Speech, 131 Harv L Rev 1598 (2018) (describing content moderation).

34 Terms of Use (Breitbart, June 3, 2015), archived at http://perma.cc/5CLE-TY27. As some have pointed out, universities also try to control speech using contract. See Robert H. Jerry II and Lyrissa Lidsky, Public Forum 2.1: Public Higher Education Institutions and Social Media, 14 Fla Coastal L Rev 55, 80-88 (2012) (discussing various universities' use of customized social media terms and conditions to attempt to set discursive norms). 
through the terms of use. For example, Lululemon's website's 8,816-word terms of use include the user's agreement to avoid comments that "defame, abuse, harass, stalk, threaten, or otherwise violate the legal rights (such as rights of privacy and publicity) of others"; the use of "racially, ethnically, or otherwise offensive language"; or posting anything "that depicts cruelty to animals." ${ }_{35}$ Birchbox, which provides beauty products on a subscription basis, prohibits (in the tenth section of its website's svelte 5,172-word terms and conditions) "unduly critical or spiteful comments of other content posted on the page or its authors." 36

A different problem is posed when parties aggrieved by a firm's services comment on third-party sites. A single negative review may have disproportionately large effects on goodwill. ${ }^{37}$ Here, obviously, the firm can't easily resort to self-help by simply removing the offending comment. In response, starting in the mid-2000s, businesses turned to the fine print: clauses in consumer contracts telling users not to negatively review their products, sometimes enforced through penalty damages. ${ }^{38}$ Such clauses (which often backfired against their drafters) are now unenforceable, following the passage of the Consumer Review Fairness Act ${ }^{39}$ making all anti-review contract clauses void. 40 That federal law was passed after the election of President Donald Trump and signed by President Barack Obama in his waning days in office. The Act, enacted at a moment when political tensions were at a historical apogee, evidences our nearly universal disdain for the fine print. ${ }^{41}$

A final set of examples comes from the platform economy. Many platform firms attempt to control users' ability to share a

35 Terms of Use (Lululemon, Sept 15, 2016), archived at http://perma.cc/8LBL-KRGR.

36 Terms and Conditions (Birchbox, 2017), archived at http://perma.cc/BGN5-NY2Y.

37 Lucille M. Ponte, Protecting Brand Image or Gaming the System? Consumer "Gag” Contracts in an Age of Crowdsourced Ratings and Reviews, 7 Wm \& Mary Bus L Rev 59, 92 (2016) ("[T] he posting of a single negative review online could cause business revenues to plummet about 25 percent or more.").

38 See Eric Goldman, Understanding the Consumer Review Fairness Act of 2016, 24 Mich Telecom \& Tech L Rev 1, 2-4 (2017) (describing the history of antireview clauses and explaining that some firms use these clauses to impose monetary fines on consumers).

39 Pub L No 114-258, 130 Stat 1355 (2016), codified at 15 USC $§ 45 b$.

$40 \quad 15$ USC $\S 45 b$.

41 Professor Danielle Citron prompts me to wonder whether the rejection of review clauses is instead an illustration of our free speech tradition. See Danielle Keats Citron, Hate Crimes in Cyberspace 199-218 (Harvard 2016) (discussing various forms of cyber harassment in the context of the First Amendment). Yet the absence of a similar public outcry against common confidentiality clauses, which are more seriously negotiated but which cause similar deprivation of market-relevant information, seems telling. 
single user account with multiple individuals. LinkedIn's User Agreement, for instance, requires that adherents: "(1) try to choose a strong and secure password; (2) keep your password secure and confidential; (3) not transfer any part of your account (e.g., connections) and (4) follow the law and our list of Dos and Don'ts." 42 Those Dos and Don'ts include an injunction whereby users promise to "[p]rovide accurate information to us and keep it updated." 43

A different kind of term appears to try to control offline customer behavior. Zipcar, for instance, permits its users (who, essentially, rent cars) to drive for services like Lyft and Uber. But, bizarrely, it attempts to use contract to control whom users transport. As its Membership Contract states, "It is prohibited to use a Zipcar vehicle for the transportation of third party goods for payment such as, but not limited to, providing courier or delivery services. In addition, it is prohibited to transport professional sports persons or professional entertainers in a Zipcar vehicle." ${ }_{4}$

The backstory of that provision would be interesting to learn. ${ }^{45}$ However, it's not unique: firms routinely enlist contract to try to control user behavior in ways that might mitigate their business risk but provide few additional legal protections. Feastly, a site that matches meal preparers with those who want to eat, makes the chefs promise not to "violate any local, state, provincial, national, or other law or regulation, or any order of a court, including, without limitation, zoning restrictions." 46 TaskRabbit, which matches the handy with the not, prohibits posting tasks that require users to cross state lines. ${ }^{47}$ Instacart, which fills your fridge, makes customers promise that they will

42 User Agreement (LinkedIn, June 7, 2017), online at http://www.linkedin.com/ legal/user-agreement (visited Mar 31, 2018) (Perma archive unavailable).

43 Id.

44 Zipcar Membership Contract_Floating Model (Zipcar Belgium, Aug 19, 2016), archived at http://perma.cc/BZL3-WKAH.

45 Avis, which owns Zipcar, has a different structure to its terms and conditions. First, it conditions assent to its use clause on an exclusion from Avis's insurance and an immediate termination of the rental. Rental Terms and Conditions: United States and Canada *4 (Avis, Apr 20, 2016), archived at http://perma.cc/5NCC-FGXR. Second, the use clause prohibits using the car to "carry passengers ... for hire," a use permitted by Zipcar. Id at *5. That is, if I were to drive Beyoncé to a concert for free, I'd violate Zipcar's terms of use, but not Avis's. If I charged her, I'd violate both provisions. If I ferried one of Beyoncé's fans home at a price, I'd violate Avis's but not Zipcar's terms. The likelihood that this parsing is apparent to anyone in the world ex ante is vanishingly low.

46 Terms and Conditions (Feastly, Oct 23, 2014), archived at http://perma.cc/289E-6TZ9.

47 TaskRabbit Terms of Service (TaskRabbit, Mar 1, 2016), archived at http://perma.cc/5CW4-94A8. 
not be intoxicated when they receive alcohol from the site. ${ }^{48}$ Box, which provides file storage, requires users to avoid "use in connection with any purposes or intended application which involves risks or dangers that could lead to death, serious bodily injury, severe physical or property damage, or . . in connection with operation of . . . nuclear facilities." 49

In considering each of these examples, we should ask: If firms really want consumers to do the things they are asking them to do, why would they use mass-market fine print to communicate their goals? And if they actually don't care if consumers listen, why bother writing such terms at all?

\section{Standard ACCOUNTS For the PERSistence of PRECATORY FINE PRINT}

This Part considers the standard explanations for precatory fine print in the modern economy and finds them, in the end, incomplete. I start with some hopefully uncontroversial propositions about the relationship between terms and behavior.

\section{A. Commercial Terms and Contract Behavior}

In some contexts, it is axiomatic that terms govern performance. ${ }^{50}$ Why else would they exist? ${ }^{51}$ The normal science of the economic analysis of contract focuses on the effect of different terms on different levels of effort: parties take greater precautions against breach when damages are higher; they are more likely to

48 Terms and Conditions (Instacart, Aug 2, 2016), archived at http://perma.cc/6EBV -LHAF.

49 Box Terms of Service (Box, Aug 1, 2017), archived at http://perma.cc/UX42-NZQ9. Notably, another product with the similar name of DropBox Inc does offer services directly to nuclear facilities, by way of a large, metal toilet. DropBox Inc. and the Sanitation Station. Portable Restroom Trailers (Sept 28, 2012), available at http://perma.cc/6KCR-QYBQ.

50 For an illustrative paper, see generally Alan Schwartz and Robert E. Scott, Contract Theory and the Limits of Contract Law, 113 Yale L J 541 (2003). Schwartz and Scott discuss an efficiency theory of firm-firm contracting, pointing out that court involvement would be limited as most contracts would be self-enforcing. Id at 556-59. It's just as axiomatic that marking the parties' obligations isn't the only thing that "contract" does. See Mark C. Suchman, The Contract as Social Artifact, 37 L \& Society Rev 91, 91 (2003) ("Contracts are many things to many people.").

51 See Suchman, 37 L \& Society Rev at 112 (cited in note 50) (providing an account of contract as a "significant gesture" that "allow[s] transacting parties to communicate messages to one another or to third-party observers"). 
perform when terms are clearly expressed; etc. ${ }^{52}$ Between firms, terms matter. ${ }^{53}$

In the consumer sphere, by contrast, most (if not all) of the extant theoretical work on the behavioral effect of terms is explicitly posed as hypothetical at best. ${ }^{4}$ True, data from lab experiments do suggest that terms-when read-can influence behavior. ${ }^{55}$ But, excepting warranties, ${ }^{56}$ terms are almost never

52 For examples and lucid analysis, see Alan Schwartz and Robert E. Scott, The Common Law of Contract and the Default Rule Project, 102 Va L Rev 1523, 1577-85 (2016).

53 This is not to say that each term is perfectly performed or that legal sanctions are necessary, as reputational concerns play important roles. For example, see Lisa Bernstein, Private Commercial Law in the Cotton Industry: Creating Cooperation through Rules, Norms and Institutions, 99 Mich L Rev 1724, 1767 (2001) (describing the role of trade associations in creating effective reputational constraints); Stewart Macaulay, NonContractual Relations in Business: A Preliminary Study, 28 Am Sociological Rev 55, 6365 (1963) (discussing reputation-based "non-legal sanctions" that often take the place of formal contract terms).

54 See, for example, Daniel Markovits and Alan Schwartz, The Myth of Efficient Breach: New Defenses of the Expectation Interest, 97 Va L Rev 1939, 1954-55 n 32 (2011) (arguing that firms are more likely to maximize monetary returns in contracts than individuals); Margaret Jane Radin, Regulation by Contract, Regulation by Machine, 160 J Inst \& Theoretical Econ 142, 145 (2004) (imagining a world of "efficacious" consumer contracts).

55 See Stanislav Mamonov and Raquel Benbunan-Fich, An Empirical Investigation of Privacy Breach Perceptions among Smartphone Application Users, 49 Computers Hum Behav 427, 432-33 (2015) (finding that the presence of legal permissions in TOS reduced smartphone users' perceptions of privacy breach but finding no significant age effects in sample of approximately 200 Amazon Mechanical Turk subjects); David A. Hoffman and Tess Wilkinson-Ryan, The Psychology of Contract Precautions, 80 U Chi L Rev 395, 41819 (2013) (finding, based on survey results, that people are more likely to protect their interests against a prospective contractual counterparty than an actual contractual counterparty and proposing psychological explanations); Eigen, $168 \mathrm{~J}$ Inst \& Theoretical Econ at 135-36 (cited in note 7); Yuval Feldman and Doron Teichman, Are All Contractual Obligations Created Equal?, 100 Georgetown L J 5, 31 (2011) ("The content of contracts, notwithstanding the legal price of breach, induces compliance.”); Tess Wilkinson-Ryan, Do Liquidated Damages Encourage Breach? A Psychological Experiment, 108 Mich L Rev 633, 665 (2010) (concluding that "the presence of a liquidated-damages clause in a contract reduces [moral] qualms and, in turn, encourages breach"); Tess Wilkinson-Ryan and Jonathan Baron, Moral Judgment and Moral Heuristics in Breach of Contract, $6 \mathrm{~J}$ Empirical Legal Stud 405, 420-21 (2009) (finding that subjects exhibited greater moral disapproval and awarded greater damages for efficient breaches as compared with breaches to avoid a loss). But see Lior Jacob Strahilevitz and Matthew B. Kugler, Is Privacy Policy Language Irrelevant to Consumers?, 45 J Legal Stud S69, S76-77 (2016) (reporting survey findings that users do not consider differences in privacy policy language relevant to whether they have authorized websites to collect personal information).

56 In many market segments, warranties are subject to strong market forces. See Yair Listokin, The Meaning of Contractual Silence: A Field Experiment, $2 \mathrm{~J}$ Legal Analysis 397, 406-10 (2010) (reporting findings that consumers correctly priced variations in warranty language); George L. Priest, A Theory of the Consumer Product Warranty, 90 Yale L J 1297, 1347 (1981) ("[T] he allocation of responsibilities . . by standardized warranties is responsive to consumer preferences, and establishes coherent economic incentives for manufacturer and consumer investments."). The two leading Federal Trade 
read. ${ }^{57}$ Thus, although contracting terms are in theory part of the consumer products that they regulate, ${ }^{58}$ studies have shown that they are not typically amenable to competitive pressures. ${ }^{59}$

Perhaps, some argue, precatory terms influence behavior through a more indirect route. There is evidence that individuals experience contracting as a ritual with some latent power, which tends to legitimate terms even when they are not read. As Professor Tess Wilkinson-Ryan puts it, "[A] policy's inclusion in a form contract may reduce the likelihood that consumers will challenge a practice using market power, informal dispute mechanisms, the court system, or the political process." 60 The very act of consent "may remind the poster of the legally binding nature

Commission studies on warranty readership (though dated) find that, generally, between 20 and 30 percent of consumers read warranties before they purchased a good, and between 50 and 80 percent read after purchase. Arthur Young \& Co, Warranties Rules Consumer Baseline Study: Final Report 58 (Federal Trade Commission 1979) (28.4 percent of all survey respondents read warranty prepurchase). These numbers provide evidence of readership rates, at least in the paper warranty context, orders of magnitudes higher than ordinary consumer contract fine print. Another datum comes from Robert A. Hillman, Online Consumer Standard Form Contracting Practices: A Survey and Discussion of Legal Implications, in Jane K. Winn, ed, Consumer Protection in the Age of the "Information Economy" 283, 290-92 (Ashgate 2006) (reporting survey findings that of the minority of law student respondents who responded that they might read terms beyond price and description, nearly all did so to look at warranty descriptions). Generally speaking, consumers are more likely to read warranties ex post than ex ante. See Shmuel I. Becher and Tal Z. Zarsky, E-Contract Doctrine 2.0: Standard Form Contracting in the Age of Online User Participation, 14 Mich Telecom \& Tech L Rev 303, 316 (2008) (arguing that scholars should more readily distinguish ex post and ex ante readership).

57 See Bakos, Marotta-Wurgler, and Trossen, 43 J Legal Stud at 19-22 (cited in note 2); Florencia Marotta-Wurgler, Will Increased Disclosure Help? Evaluating the Recommendations of the ALI's "Principles of the Law of Software Contracts", 78 U Chi L Rev 165, 179-81 (2011).

58 See Arthur Allen Leff, Contract as Thing, 19 Am U L Rev 131, 146-47 (1970) (characterizing adhesion contracts as just one part of "a unitary, purchased bundle").

59 See, for example, Florencia Marotta-Wurgler, Competition and the Quality of Standard Form Contracts: The Case of Software License Agreements, 5 J Empirical Legal Stud 447, 451 (2008) (concluding that "there is no evidence" that "greater market power is associated with more pro-seller standard terms"). Field experiment data is generally in accord. See, for example, Enrique Seira, Alan Elizondo, and Eduardo Laguna-Müggenburg, Are Information Disclosures Effective? Evidence from the Credit Card Market, 9 Am Econ J: Econ Pol 277, 291-98 (2017) (finding very small or negative effects of personalized disclosures on credit card account holders' behavior in a large randomized control trial); Bruno Ferman, Reading the Fine Print: Information Disclosure in the Brazilian Credit Card Market, 62 Management Science 3534, 3545 (2016) (reporting that, in a randomized field experiment, more salient disclosure of credit card interest rates did not affect consumer behavior except in high-risk clients); Sumit Agarwal, et al, Regulating Consumer Financial Products: Evidence from Credit Cards, 130 Q J Econ 111, 147-52 (2015) (finding that the effect of a "months-topayoff" disclosure could not be precisely estimated).

60 Wilkinson-Ryan, 103 Cornell L Rev at 165 (cited in note 7). 
of agreement."61 Once reminded, users may "reconsider their communications." 62

That is, we all know that some terms apply, and we may be behaviorally influenced by what we each imagine to be the rules of the road. ${ }^{63}$ To be concrete, when we agree to a user agreement before commenting online, perhaps we correctly intuit that the agreement tells us not to be a jerk and behave better as a result. However, even the most cutting-edge research has only begun to ask about individuals' naïve views of consumer contract terms. ${ }^{64}$ It seems unlikely that firms know more.

61 Nancy S. Kim, Web Site Proprietorship and Online Harassment, 2009 Utah L Rev $993,1015$.

62 Id. But see David A. Hoffman and Zev J. Eigen, Contract Consideration and Behavior, 85 Geo Wash L Rev 351, 385-88 (2017) (noting the lack of evidence of changed user behavior resulting from user consent to ostensibly legally binding agreements and arguing for new forms of formation formality); Monika Leszczyńska, Think Twice before You Sign! An Experiment on a Cautionary Function of Contract Formalities * 12 (unpublished manuscript, Sept 26, 2016), archived at http://perma.cc/8CBF-MD94 (reporting survey findings that individuals acted more impulsively when clicking a box than when signing their name during interactions with websites' forms).

63 Wilkinson-Ryan provides some evidence in support of this hypothesis. WilkinsonRyan, 103 Cornell L Rev at 164-65 (cited in note 7). See also Ayres and Schwartz, 66 Stan L Rev at 600-01 (cited in note 1) (discussing divergent consumer views as to what privacy policies say); Eigen, $168 \mathrm{~J}$ Inst \& Theoretical Econ at 135-37 (cited in note 7) (showing that, as individuals spent more time reading the contract ex ante, they were more likely to perform in accordance with its terms ex post). This sort of intuition gives rise to the famously unsuccessful Restatement (Second) of Contracts $§ 211$, otherwise known as the reasonable expectations doctrine. As the Restatement puts it, "Although customers typically adhere to standardized agreements and are bound by them without even appearing to know the standard terms in detail, they are not bound to unknown terms which are beyond the range of reasonable expectation.” Restatement (Second) of Contracts, § 211(f) (1979).

64 There are a number of papers that discuss the terms that consumers expect, but which do not focus on performance obligations. For example, consumers do not seem to accurately recall the presence of certain clauses in some consumer contracts. See, for example, Jeff Sovern, et al, "Whimsy Little Contracts" with Unexpected Consequences: An Empirical Analysis of Consumer Understanding of Arbitration Agreements, $75 \mathrm{Md} \mathrm{L}$ Rev 1, 41 (2015) (reporting survey results in which few consumers recalled seeing an arbitration agreement in a contract that contained one); Debra Pogrund Stark, Jessica M. Choplin, and Eileen Linnabery, Dysfunctional Contracts and the Laws and Practices That Enable Them: An Empirical Analysis, 46 Ind L Rev 797, 813-20 (2013) (reporting survey findings showing that real estate consumers exhibited a poor understanding of waivers of remedies); Zev J. Eigen, The Devil in the Details: The Interrelationship among Citizenship, Rule of Law and Form-Adhesive Contracts, 41 Conn L Rev 381, 414-16 (2008) (reporting survey results in which only 17 percent of an employee sample recalled that an employment agreement they signed contained an arbitration clause). There is a more robust literature about naïve views of legal rules outside of contract. For example, see Gregory N. Mandel, Anne A. Fast, and Kristina R. Olson, Intellectual Property Law's Plagiarism Fallacy, 2015 BYU L Rev 915, 946-47 (reporting experimental results on individuals' incorrect views about the content of intellectual property law). 
In fact, if consumer contracts are really just adding an extra feeling of heft behind implicit performance terms, why should firms insert any explicit behavioral terms at all, especially because term drafting is costly and may result in blowback? ${ }^{65}$ Some might respond that firms hope to influence the collective understanding of what terms are normal by pushing out particular language - that is, to create collective reasonable expectations one term at a time. ${ }^{66}$ The idea isn't actually so outlandish over a long enough time. ${ }^{67}$ But it is hard to imagine that any firms follow this kind of generational strategy. ${ }^{68}$

Thus, the best extant empirical evidence about how ordinary precatory fine print functions concludes that it doesn't, at least with respect to ex ante behavioral regulation and deterrence.

\section{B. The Standard Account: The Option Value of Fine Print}

Given that terms are unread, why do firms waste the time drafting them? Most argue, in one form or another, that even if terms don't affect behavior ex ante, they certainly can ex post. That claim is common with respect to terms that limit consumer rights: explicit terms make legal defenses stronger. ${ }^{69}$ However, the defense doesn't require all terms to be litigated, and it

\footnotetext{
65 For general discussion of a type of blowback, see Ethan J. Leib and Zev J. Eigen, Consumer Form Contracting in the Age of Mechanical Reproduction: The Unread and the Undead, 2017 U Ill L Rev 65, 101-02.

66 See id at 79 ("The more we fail to resist zombie [boilerplate] contracts, the easier it is for drafting entities to assert that they hold a reasonable belief that individuals manifesting assent to terms would still do so, even in the face of more and more rightsencroaching terms.").

67 It is hard to find data that supports or refutes the idea that individuals' subjective expectations of contract terms have changed. And yet, in the 1980s, for example, forum selection clauses were seen as controversial and seemingly limited to negotiated deals. However, over time (helped by the Supreme Court) they have become anodyne. See Carnival Cruise Lines v Shute, 499 US 585, 593-94 (1991) (broadening the enforceability of standardized forum selection clauses in large part because they save litigation costs).

68 For one, it might not work! There is evidence from the privacy context that subjective views about Fourth Amendment privacy may be relatively fixed. See Matthew B. Kugler and Lior Jacob Strahilevitz, The Myth of Fourth Amendment Circularity, 84 U Chi L Rev 1747, 1794-95 (2017) (finding that, while Supreme Court decisions had short-term effects on the public's views on lawful surveillance, these effects disappeared over time). After reading a copy of this Article, Professor Danielle Citron, however, suggested to me that Facebook's real name policy might be an example of a firm with just such a long-term commitment in mind, based on Mark Zuckerberg's personal commitments.

69 Eigen, An Experimental Test at *5 (cited in note 15) (describing the common notion that, without media use contracts, "companies would be left with greater costs of policing implied contractual rights in court, instead of being able to rely on the explicit wording of the 'fine print"').
} 
acknowledges that in fact firms rarely insist on the actual language in their consumer contracts. Rather, the terms are used opportunistically, policing consumers on the margin. ${ }^{70}$ The fine print functions as an option.

This view is most closely associated with a short essay by Professor Lucian Bebchuk and former Judge Richard Posner. ${ }^{71}$ Bebchuk and Posner claim that aversive terms in consumer contracts are intended to give firms the flexibility to police "egregious" conduct that is not easily reducible to semantic contract terms. ${ }^{72}$ By giving firms "discretion" in dealing with consumers, terms that look one-sided turn out in practice to harm few consumers. ${ }^{73}$ The firm can choose to exercise its rights when it is in its interest to do so. These options-even if implicit-have value for their holders. ${ }^{74}$

This option-centered account sheds light on some puzzling features of current practice outside of the conventional context of defenses to obligation. Precatory terms are sometimes "exercised," though not in court. 75 Reference to them makes it easier for sites to ban abusive commentators without recourse to legal process, and they serve as a defense in actions by commentators and the third parties they might have harmed. ${ }^{76}$ Generally, firms

70 Bebchuk and Posner, 104 Mich L Rev at 833-34 (cited in note 23) (describing how firms use their contractual terms to enforce policies against consumers who do not act in good faith). See also Johnston, 104 Mich L Rev at 877 (cited in note 5) ("The strategy of allowing employees the discretion to grant case-specific benefits beyond those that are required by the standard-form contract can be seen to be a sophisticated way for the firm to grow its revenues.").

71 See generally Bebchuk and Posner, 104 Mich L Rev 827 (cited in note 23).

72 Id at 831.

73 Id.

74 See, for example, George S. Geis, Book Review, Economics as Context for Contract Law, 75 U Chi L Rev 569, 585-86 (2008) (explaining the importance of option theory to contract law); Robert E. Scott and George G. Triantis, Embedded Options and the Case against Compensation in Contract Law, 104 Colum L Rev 1428, 1460 (2004) (describing the option to behave opportunistically as a valuable part of contracting).

75 See Ammori, 127 Harv L Rev at 2274-78 (cited in note 32) (describing the implementation of speech codes contained in TOS at various digital companies through "private jurisprudence").

76 But see Kim, 2009 Utah L Rev at 1028-29 n 144 (cited in note 61) (noting that a firm was investigated for consumer fraud for failing to enforce its own terms and conditions against abuse and subsequently changed its terms). The fact that most actions against firms that ban content that is barred by their TOS fail on $\S 230$ grounds makes the marginal legal utility of TOS particularly puzzling. See 47 USC $\S 230$ (c)(2)(A) ("No provider or user of an interactive computer service shall be held liable on account of any action voluntarily taken in good faith to restrict access to or availability of material that the provider or user considers to be ... objectionable."). 
will prefer to point out explicit reasons for self-help to consumers so as to avoid reputational blowback. ${ }^{77}$ This works because consumers generally think contracts are legitimate-even adhesive contracts on the web. ${ }^{78}$ Thus, precatory consumer contract terms permit firms to cheaply weed out particular bad consumers from communities that would otherwise be contaminated by their presence. ${ }^{79}$

Options can also be exercised to police competitors. ProCD $v$ Zeidenberg, ${ }^{80}$ an early internet law case, fits that fact pattern. In ProCD, the court enforced a noncommercial use limitation on use of a database (which was otherwise not subject to copyright). Judge Frank Easterbrook explicitly framed the problem as one of permitting price discrimination by preserving the firm's option to police competitors who came dressed as consumers, writing that "Zeidenberg wants to use the data without paying the seller's price." ${ }^{11}$ Or contracts might be used as evidence in suits that firms tried (but failed) to prevent bad conduct, like harassing speech or copyright infringement. ${ }^{82}$ The terms, in short, are a defensive shield behind which the firm has room to maneuver. ${ }^{83}$

77 See Ponte, 7 Wm \& Mary Bus L Rev at 78-79 (cited in note 37) (“Often, nondisparagement provisions are framed in a manner that keeps the primary focus on the business investment in the brand's development and establishment of its goodwill in the marketplace, while obscuring the effort to limit consumer speech."). See also Becher and Zarsky, 14 Mich Telecom \& Tech L Rev at 322-28 (cited in note 56) (discussing ways that consumers learn of terms ex post).

78 See Meirav Furth-Matzkin, On the Unexpected Use of Unenforceable Contract Terms: Evidence from the Residential Rental Market, $9 \mathrm{~J}$ Legal Analysis 1, 41-42 (2017) (noting that, when contracts include "unenforceable and misleading terms," consumers who are unfamiliar with the law may rationally believe that terms are enforceable and binding when they are not); Wilkinson-Ryan, 103 Cornell L Rev at 121 (cited in note 7) (arguing that firms use boilerplate because it may chill complaints); Dennis P. Stolle and Andrew J. Slain, Standard Form Contracts and Contract Schemas: A Preliminary Investigation of the Effects of Exculpatory Clauses on Consumers' Propensity to Sue, 15 Behav Sci \& L 83, 91-92 (1997) (reporting survey findings that "the presence of [boilerplate] exculpatory language did have a deterrent effect on participants' propensity to seek compensation").

79 See, for example, Citron and Norton, 91 BU L Rev at 1468-69 (cited in note 24) (describing how online platforms use their terms of use to justify removing hate speech).

$80 \quad 86$ F3d 1447 (7th Cir 1996).

81 Id at 1454.

82 See Citron, Hate Crimes in Cyberspace at 169-72 (cited in note 41).

83 As Ed Ferguson, Vice President and Associate General Counsel at IAC, and Michael Cheah, General Counsel at Vimeo, explained to me, the TOS provide protection for the firm-the freedom of action to exclude users or manage disputes. Telephone Interview with Ed Ferguson and Michael Cheah (Apr 28, 2017) ("Interview with Ed Ferguson and Michael Cheah") (on file with author). 
Although it has significant explanatory force, the option theory doesn't explain some puzzling aspects of the consumer contracting universe. ${ }^{84}$ For one, enforcing buried terms may result in perverse effects. I have already mentioned reputational harms, but consider also the possibility that an entire industry may become tainted by using contracts in opportunistic ways. Consumers will then actively work to either avoid dealing with firms or behave unscrupulously in turn. This description marks the current state of both the cable TV and the cellphone sectors. ${ }^{85}$

Even if firms can avoid reputational sanctions, the option explanation simply ignores the possibility that firms might really

84 See Feldman \& Teichman, 100 Georgetown L J at 31, 49 (cited in note 55) (discounting the option explanation after experimental study about individual motivations). Professor Guy Rub, in a survey of 279 reported decisions analyzing the copyright/contract nexus, found no examples of a consumer sued for breach of an intellectual property standard form contract. Rub, $103 \mathrm{Va}$ L Rev at 1198 (cited in note 13).

85 For example, consumers often try to switch cellphone carriers notwithstanding cancellation fees. The result is large consumer debts. See In re Cellphone Termination Fee Cases, 193 Cal App 4th 298, 306 (2011) (explaining that Sprint assessed $\$ 299,473,408$ in early termination fees during the class period, but only $\$ 73,775,975$ was paid by consumers). See also Consumer Credit Reports: A Study of Medical and Non-Medical Collections *19 (Consumer Financial Protection Bureau, Dec 2014), archived at http://perma.cc/U4FT -K2EQ (showing that telecom debts, at 8.7 percent, represent the second largest form of debt referred to collection agencies that shows up on consumer credit reports, after medical care). But firms rarely are made whole through debt collection, and typically they are thus left without real recourse for breach. See id at *34 (presenting data indicating that the average payment rate for debts referred to collection across six industries is only 6.7 percent). The move to "no-contract clauses" is in this sense possibly a reaction to the failure of termination clauses in fixed-duration agreements. There is an interesting dynamic here, whereby no-contract clauses may be in part an attempt by the firm to make salient the alternative (termination fees) and thus affect the behavior of the small percentage of consumers who stick with a contract deal. That is, by advertising "no contract," the firm makes the remaining part of its consumer base realize that they are buying shackles and become constrained accordingly. Evidence for this proposition is suggestive: the churn rate during the period from 2013 - the year when T-Mobile was the first major carrier to introduce a no-contract plan-to 2017 shows a significant drop, from 3.3 percent to 2.29 percent. Average Monthly Churn Rate for Wireless Carriers in the United States from 1st Quarter 2013 to 4th Quarter 2017 (Statista, 2018), online at http://www.statista.com/ statistics/283511/average-monthly-churn-rate-top-wireless-carriers-us/ (visited Mar 31, 2018) (Perma archive unavailable). Additionally, as no-contract plans became more common, the media was particularly quick to argue that two-year agreements were akin to being in jail. See, for example, Alison Griswold, So Long, Cellphone Contracts. You Won't Be Missed. (Slate, Aug 18, 2015), archived at http://perma.cc/DFJ5-7UXE (arguing that, while most consumers will be happy to see the end of two-year contracts, some who do not mind the commitment and do not worry about having the newest phones will be better off staying on two-year plans); Joanna Stern, Kill the Wireless Contract! Buy Your Own Phone (Wall St J, Feb 25, 2015), online at http://www.wsj.com/articles/kill-the-wireless-contract -buy-your-own-phone-1424807865 (visited Mar 31, 2018) (Perma archive unavailable) ("Without much thought, I did what most Americans do every two years: I agreed to be locked in by a multibillion-dollar wireless company."). 
want to govern ex ante consumer behavior-that is, to use contract to shape consumers' activity in the absence of injury. One can't really blame theorists for their lack of curiosity: they are observing a world of buried and hidden terms. But why has the market produced that outcome when firms appear to have significant incentives and capabilities to maximize the readership of at least some of their contracts? 86

Perhaps we can attribute the lack of innovation in consumer contracts to a market failure created by a particular, villainous guild.

\section{Legal Market Failure}

Whether because of social pressures that reward conformity, ${ }^{87}$ the bar's monopoly, ${ }^{88}$ a desire to please the client, ${ }^{89}$ the fear of legal liability, or network effects, ${ }^{90}$ lawyers generally are cast as reluctant contract innovators. Terms and conditions, as "convenient and known instruments" in the legal toolset, come easily to hand for lawyers who are tasked by their clients with solving

86 See, for example, Hoffman, 91 NYU L Rev at 1639 n 189 (cited in note 7) (discussing firm innovation around dynamic webpages that utilize data about prospective customers with the goal of encouraging them to shop); Robert W. Gomulkiewicz, Getting Serious about User-Friendly Mass Market Licensing for Software, 12 Geo Mason L Rev 687, 69596 (2004) (describing the benefits to firms of creating contracts that consumers can understand ex ante, which include building goodwill and ensuring that consumers do not exceed the scope of their rights).

87 See Joshua Fairfield, The Cost of Consent: Optimal Standardization in the Law of Contract, 58 Emory L J 1401, 1409 (2009) (noting that lawyers reuse language to "save themselves drafting costs, economize on learning costs, reuse 'safe' language that has been vetted by courts, and signal to prospective counterparties that the contract drafter does not seek an unfair advantage").

88 See Hadfield, Rules for a Flat World at 228-37 (cited in note 8) (“[A] system based on this level of uniformity in thinking is an almost impossible environment for transformative change.").

89 See Eric A. Zacks, Contract Review: Cognitive Bias, Moral Hazard, and Situational Pressure, 9 Ohio St Entrepreneurial Bus L J 379, 417 (2015) (explaining that the desire to please the client induces an attorney "to revise the contract in a manner that minimizes the possibility of the revisions disrupting the transaction").

90 See Marcel Kahan and Michael Klausner, Standardization and Innovation in Corporate Contracting (or "The Economics of Boilerplate"), 83 Va L Rev 713, 725-27 (1997) (describing "network benefits" as a "set of advantages . . . available to a firm that adopts a contract term that is or will become contemporaneously used by many firms for a significant period of time"). 
consumers' behavioral problems. ${ }^{91}$ More exotic forms of regulation, like visceral notice, ${ }^{92}$ are both unproven and could potentially backfire. ${ }^{93}$ The result is an allegedly inefficient equilibrium. Zev Eigen makes this argument most bluntly:

Lawyers at a firm do not like to be sued for malpractice any less than in-house counsel enjoy being fired. So generally speaking, it is a wise and rational self-preserving strategy to avoid reinventing the wheel or doing something differently from every other lawyer working for other similarly situated companies or firms. If every lawyer before you relied on terms and conditions to solve a problem, you should too. How could a client fault you for using the same tactics as every other lawyer?94

Eigen is far from the only commentator to suggest that lawyers have failed to offer creative and value-maximizing solutions to clients in the new economy. ${ }^{95}$ As Professor Gillian Hadfield has recently argued, many entrepreneurial businesses have come to conclude that large law firms cannot solve their business problems "at any price." 96 She points to the complaints of the general counsel of CBS, who finds that lawyers create terms and conditions that either "lock [content] down" or entirely give it away. ${ }^{97}$ CBS—and other companies navigating today's economy—sought

91 Eigen, An Experimental Test at *4 (cited in note 15).

92 See Calo, 87 Notre Dame L Rev at 1030 (cited in note 24) ("Visceral notice ... does not necessarily rely on describing practices in language or symbols. Rather, it leverages a consumer's very experience of a product or service to warn or inform.").

93 Though lawyers are traditionally seen as risk averse with respect to new technologies, they are often also criticized for taking risks by drafting to the edge of what's enforceable. Sometimes, we can't win. See Study of Uniform Commercial Code Memoranda Presented to the Commission and Stenographic Report of Public Hearing on Article 2 of the Code, NY State Law Revision Commission, Legislative Doc No 65 at 177 (1954) (statement of Professor Karl Llewellyn) ("Any engineer makes his construction within a margin of safety, and a wide margin of safety, so that he knows for sure that he is getting what he is gunning for. The practice of business lawyers has been, however . . . to draft . . . to the edge of the possible.").

94 Eigen, An Experimental Test at *4 (cited in note 15).

95 See, for example, Royce de R. Barondes, The Business Lawyer as Terrorist Transaction Cost Engineer, 69 Fordham L Rev 31, 52 (2000) (describing how drafting hidden contractual terms impacts lawyers' reputations even when they are actually advancing clients' interests); Scott Edward Walker, Top 10 Reasons Why Entrepreneurs Hate Lawyers (Venture Hacks, Jan 14, 2010), archived at http://perma.cc/256G-BU2M (including "overlawyering" by using a "one-size-fits-all approach to deals" in a list of reasons why entrepreneurs hate lawyers).

96 Hadfield, Rules for a Flat World at 188 (cited in note 8).

97 Id. 
a Goldilocks solution. But it was "very hard to locate the lawyers who know how to think like that."98

The former general counsel of Tumblr, Ari Shahdadi, describing Tumblr's terms of service (TOS) revision process (about which I say more in Part III.A), noted that "law firm feedback was beyond useless, as their assessment of risks is way off and they can't really balance the interests of users" and that "[n]o law firms are good at this." 99 When asked what institutional barriers exist to widespread use of precatory consumer contracts, he squarely laid the blame at the feet of the bar:

[D] ecaying and venal legal institutions [ ] surround US companies and don't highlight the benefits (and low risks) of user-friendly contracts-a federal judiciary that routinely kowtows to concentrated financial power (ergo allowing class action waivers and mandatory arb[itration] clauses), a corrupt and self-interested bar that invests in inefficiency and hooks for meritless plaintiffs' suits, that same bar being insanely overly conservative on the defense/advice side to protect their inefficient and exorbitant fee structures, etc. ${ }^{100}$

Similarly, Michal Rosenn, the former general counsel of Kickstarter, suggested that outside law firms have a "very lawyerly risk averse approach" and that, as a consequence, they are likely to avoid changes to consumer-facing terms. This is true both in traditional "Biglaw" and in firms that serve entrepreneurs: general counsel, by virtue of being embedded in the business, develop a healthier appetite for risk-taking and a sense of the relative unimportance of small-bore legal problems. ${ }^{101}$

Etsy's representatives, when prompted to reflect on barriers to change, also mentioned risk aversion as a driver, though not standing alone:

It's hard to know for sure why other companies haven't [innovated], but there are certainly costs associated with making significant changes to user policies. Some of those

98 Id at 190.

99 Email from Ari Shahdadi to David A. Hoffman (Mar 22, 2017, 3:08 pm EDT) ("Email from Ari Shahdadi, 3:08 pm") (on file with author).

100 Email from Ari Shahdadi to David A. Hoffman (Mar 22, 2017, 5:45 pm EDT) ("Email from Ari Shahdadi, 5:45 pm") (on file with author).

101 Telephone Interview with Michal Rosenn (Mar 24, 2017) ("Interview with Michal Rosenn”) (on file with author). 
costs-in-house counsel's time, translation, and outside counsel review-are relatively concrete and easy to quantify. Others, such as the risks of attracting unwanted attention from users or plaintiff's counsel or omitting some crucial piece of legal language, are harder to evaluate. But we suspect that some combination of cost sensitivity and risk aversion is responsible for many companies['] continued use of more oldfashioned policies. ${ }^{102}$

As a lawyer who worked at Etsy on its terms of use project lamented, outside counsel "will never give you what you want[.] [Y]ou have to hold the pen ... [because] [t]hey focus on magic words." 103

It is possible that American lawyers-and the law schools that produce them-are to blame for the failure of consumer contracts to offer anything beyond option values for firms. It might be that in a world in which lawyers were forced to directly compete against other sorts of professional services, consumer contracts would be better tailored to firms' needs (though the examples we see from less regulated jurisdictions don't compel that point). ${ }^{104}$ But there are also reasons to be skeptical about an account that posits that lawyers are entirely to blame.

First, though it is true that the worst thing you can say about a legal argument is that it is creative, it's nonsense to deny the existence of legal innovations, even in the context of consumer contract fine print. For example, in the mid-1990s, Alan Kaplinsky, a Philadelphia-based big-firm lawyer, invented the class action waiver in a consumer contract. ${ }^{105}$ That innovation created enormous value for his clients. ${ }^{106}$ Other lawyers built on

102 Email from Bonnie Broeren, Head of Policy, Etsy, to David A. Hoffman (Mar 28, 2017, 2:17 pm EDT) (“Email from Bonnie Broeren, 2:17 pm") (on file with author), quoting Matthew Glick, Senior Product and Commercial Counsel, Etsy.

103 Telephone Interview with Hissan Bajwa, former senior counsel, Etsy (Apr 4, 2017) ("Interview with Hissan Bajwa") (on file with author).

104 Notably, though lawyers abroad face fewer barriers to competition, they have not produced (to my knowledge) distinctively communicative legal terms. That's true, although "new types of business models for legal work" are flourishing, including "joint venture[s] between lawyers, software engineers, and business experts." Hadfield, Rules for a Flat World at 241-45 (cited in note 8) (offering a description of the UK's deregulatory system).

105 Chris Mondics, A Pioneer in the Class Action Lawsuit Tug-of-War (Philly.com, Nov 11, 2015), archived at http://perma.cc/K6KC-2GWG.

106 For a general discussion of the value of contractual innovation, see Kevin E. Davis, Contracts as Technology, 88 NYU L Rev 83, 88-97 (2013) (discussing how innovation in contracts can beneficially change parties' behavior). 
Kaplinsky's invention, eventually (through a deliberate strategy of creation and refinement) creating a clause for AT\&T that applied waivers to arbitration in a way that survived Supreme Court review. 107

Second, many firms have apparently succeeded in communicating with their users using governance documents. They've done so by moving from "contract" to "policy." As Professor Eric Goldman argued in 2008:

[B] ehavioral restrictions that do not need to be specifically barred in the user agreement can be moved into a separate statement of community norms/standards. This way, users are told what they can do and not do, but the statement does not have the force of law. Ideally, other users can be given tools to help them enforce the community norms. Even better, the norms can be posted on a wiki so that the site's users can help update them as the site's community evolves.

$\cdots$

[A] separate non-legal document may be a more effective tool to communicate site expectations than embedding those rules in a user agreement that no one will read. 108

Such guidelines are now commonly used to regulate user conduct in contexts in which firms find such regulation to be important. ${ }^{109}$ The relationship between nonbinding guidelines and

107 See David Horton, The Shadow Terms: Contract Procedure and Unilateral Amendments, 57 UCLA L Rev 605, 654-56 (2010) (explaining how AT\&T has changed its class arbitration waiver clause over time, seeking to create a version that is upheld by courts). See also AT\&T Mobility LLC v Concepcion, 563 US 333, 340, 352 (2011) (holding that the California Supreme Court's rule, which had resulted in AT\&T's arbitration waiver being found "unconscionable," was preempted by federal law).

108 Eric Goldman, Lori Drew Conviction Reflections, Part 3 of 3: Lessons for CyberLawyers Drafting User Agreements (Technology \& Marketing Law Blog, Dec 16, 2008), archived at http://perma.cc/4DDE-5T44.

109 An example is a firm that Professor Goldman once worked with-Nextdoor. The site's "community guidelines" effectively contain a series of norms that don't read as simple rehashed terms of use. Community Guidelines (Nextdoor, Dec 7, 2017), archived at http://perma.cc/AV66-E36H. Another example is the intellectual property guidelines at Vimeo, which were developed by the community team at that firm-with oversight from legal-to create a communicatively rich way to explain to users the intellectual property rules that the site wanted to enforce. Help Center/Vimeo Guidelines (Vimeo, 2018), archived at http://perma.cc/NP4B-PDPD. As the firm's general counsel pointed out to me, the firm in those guidelines uses phrases and a tone ("Don't be a creep") that it would never use in its terms of use. Interview with Ed Ferguson and Michael Cheah (cited in note 83). 
terms of use is an interesting one. It seems that as firms grow larger and more complex, it becomes ever more difficult to maintain the separation: the policies increasingly refer back to their enabling contracts, reducing the acoustic separation that gave the former their communicative push. The result is that, at least for some firms, using consumer contracts to shape behavior would seem to be a useful innovation.

The next Part identifies a few firms that seem to have experimented in this vein.

\section{COMMUNiCATING THROUGH CONTRACTS}

So far, I have described fine print that was traditional in both form and placement. That is, it wasn't frontloaded in the contract but rather placed somewhere in its guts, and it looked and sounded like it was written by and for lawyers. I've suggested that conventional explanations for this phenomenon rest on either believing that there's simply insufficient demand for communicative terms to make them worthwhile to produce or that, while demand exists, the market fails to match it because of the bar's monopoly.

In this Part, I provide some examples that together suggest these prevailing accounts are, if not wrong, then at least incomplete. Sometimes, firms create fine print that at least sounds like it was written by a human. Whether these counterexamples provide the exception to the rule, or its undoing, is a subject I take on later in the Article.

Consider Bumble, a dating app, which functions somewhat like the better-known Tinder, except that women must initiate conversations. Indeed, the app was founded by Whitney Wolfe, who had previously helped to start Tinder. ${ }^{110}$ Bumble's terms and conditions, like those of many other modern firms, control intellectual property rights and regulate user behavior. But Bumble's approach sounds different. It begins with a jaunty paragraph:

Hey guys! Welcome to Bumble's Terms and Conditions of Use (these "Terms"). Our lawyers insist that we impose rules on users to protect all of our hard work. This is a contract between you and Bumble Trading Inc and we want you to know yours and our rights before you use the Bumble application

110 Leora Yashari, Meet the Tinder Co-Founder Trying to Change Online Dating Forever (Vanity Fair, Aug 7, 2015), online at http://www.vanityfair.com/culture/2015/08/ bumble-app-whitney-wolfe (visited Mar 31, 2018) (Perma archive unavailable). 
("App"). Please take a few moments to read these Terms before enjoying the App, because once you access, view or use the App, you are going to be legally bound by these Terms (so probably best to read them first!). ${ }^{111}$

And the rest of the terms, though substantively identical to those of a thousand other sites, are interspersed with exclamation points and snark. Some of the wording explicitly attempts to remind users of offline norms of courtesy and reciprocity:

Also, we don't appreciate users doing bad things to Bumblewe've worked hard on our creation, so scraping or replicating any part of the App without our prior consent is expressly prohibited. ${ }^{112}$

The eleventh section of the terms, headed "Miscellaneous," is introduced as follows: "Firstly, those standard clauses at the end of most contracts (boring, we know)." 113 After users have agreed that the terms may be unilaterally modified, the terms then flag that "[s]ome more legal mumbo jumbo" is on its way, including a waiver of class action relief and choice of forum clauses, all presented in their original legal language. ${ }^{114}$

Later, I return to Bumble's story; for now, consider how different such terms sound from the ordinary drone of end-user license agreements (EULAs) that you haven't read. (To remind yourself what that drone sounds like, take a look at iTunes's EULA, as it's likely at hand.) To the extent that you found Bumble's terms refreshing, consider the incentive structures that produced them. Doesn't everyone now agree that no one reads consumer contracts and they are, at best, a series of weak option clauses? If that's true, what could drive Bumble (and other firms) ${ }^{115}$ to create terms that are moderately funny and easier to parse? ${ }^{116}$

111 Terms and Conditions of Use (Bumble, Sept 6, 2017) ("Bumble Terms and Conditions"), archived at http://perma.cc/R9GT-N2MS.

112 Id.

$113 \mathrm{Id}$.

$114 \mathrm{Id}$.

115 See, for example, Terms of Use (Netflix, Aug 1, 2017), archived at http://perma.cc/4VRU-FV7E (beginning its terms of use with the possibly disarming, or at least chipper, exhortation: "Welcome to Netflix!"); Jet Terms of Use (Jet, Sept 12, 2016), archived at http://perma.cc/CK9J-RXZH ("We apologize for the all-caps shouting we're about to do, but these parts are important. ("takes deep breath*)").

116 To be precise, they are law school funny. 
To answer that question, I talked with numerous participants in the consumer contracts industry and was led to focus on a few platform economy firms that have written terms that appear to actually seek to communicate with, and influence, their users. ${ }^{117}$ Through a series of semistructured interviews, I asked general counsel at Tumblr, Kickstarter, and Etsy, as well as AirBnb and Bumble, how they came to write the terms they did and what they sought to gain. ${ }^{118}$ All are businesses that rely on participation by users, and all have cultivated relationships with their "community" that revolve, to one degree or another, around trust. ${ }^{119}$ So let us examine the mass contracts they created.

\section{A. Tumblr: Because They Cared}

Consider first the case of Tumblr. Ari Shahdadi, describing his work as the general counsel at Tumblr, listed this revision of the TOS as one of his great successes. ${ }^{120}$ When he arrived on the job in May 2011, he thought the TOS "need[ed] to get re-written. ... It was not in keeping with [] the trust relationship that David

117 There are, of course, other firms with excellent, communicative terms. The examples here are not intended to be exclusive, but rather the result of the limits of my contacts. For discussion of Pinterest, see Elizabeth Townsend Gard and Bri Whetstone, Copyright and Social Media: A Preliminary Case Study of Pinterest, 31 Miss C L Rev 249, 270-75 (2012) (describing Pinterest's evolution of its terms and summarizing that "[e]ssentially the Terms of Service are the same [as a previous iteration], with one notable difference: the new Terms can actually be understood by the average user"). An old (but still well-known) example is Borland's "No-Nonsense License Statement," which urged users to treat the software "just like a book." Thom Holwerda, Borland in the 1980s: "Treat Software Just Like a Book" (OSNews, Oct 15, 2009), archived at http://perma.cc/CRH3 -LQ6P. See also Terms of Service (500px), archived at http://perma.cc/WWW8-GYHA (presenting terms of use in two columns: the legal language on the left and a section headed "Basically" on the right containing a paraphrased version).

118 A semistructured interview follows a "general outline of the topics to be covered during the interview but is free to follow the flow of the interview in deciding when and how to pursue each thread." Robert M. Lawless, Jennifer K. Robbennolt, and Thomas S. Ulen, Empirical Methods in Law 73 (Wolters Kluwer 2d ed 2016). They can be particularly helpful in interviewing attorneys. I interviewed Etsy's policy team and Tumblr's former general counsel by email and conducted all other conversations by phone. I sent a preliminary draft of this Article to the sources and offered them an opportunity to correct any direct quotes and suggest changes to my interpretation. (I incorporated all edits to direct quotes from interviews and some of the suggested changes to interpretation.) Each interview or email exchange focused on four basic topics: Why did the firm come to create the terms it did, what was the process of their drafting, what barriers did they face, and how did they measure or evaluate success?

119 Sharing economy firms are typically built on trust between strangers. See, for example, Calo and Rosenblat, 117 Colum L Rev at 1634 (cited in note 8).

120 Ari Shahdadi, I Fought the Law and the Law Won (Lawyerin', Sept 25, 2015), archived at http://perma.cc/CUJ6-ZMPX. 
[Karp, Tumblr's founder,] had built with the user base. So that was [] on my list [] day one."121 Here are what Tumblr's terms (in part) looked like before the edit:

Figure 1: TUMBLR TOS (2010) ${ }^{122}$

Accepting the Terms of Service

The purpose of this website, www.tumblr.com (the "Site"), owned and operated by Tumblr, Inc. ("Tumblr"), a Delaware corporation, is to provide web publishing services. Please read these terms of service ("Agreement") carefully before using the Site or any services provided on the Site (collectively, "Services"). By using or accessing the Services, you agree to become bound by all the terms and conditions of this Agreement. If you do not agree to all the terms and conditions of this Agreement, do not use the Services. The Services are accessed by You ("Subscriber" or "You") under the following terms and conditions:

1. Access to the Services

Subject to the terms and conditions of this Agreement, Tumblr may offer to provide the Services, as described more fully on the Site, and which are selected by Subscriber, solely for Subscriber's own use, and not for the use or benefit of any third party. Services shall include, but not be limited to, any services Tumblr performs for Subscriber, as well as the offering of any Content (as defined below) on the Site. Tumblr may change, suspend or discontinue the Services at any time, including the availability of any feature, database, or Content. Tumblr may also impose limits on certain features and services or restrict Subscriber's access to parts or all of the Services without notice or liability. Tumblr reserves the right, at its discretion, to modify these Terms of Service at any time by posting revised Terms of Service on the Site and by providing notice via e-mail, where possible, or on the Site. Subscriber shall be responsible for reviewing and becoming familiar with any such modifications. Use of the Services by Subscriber following such modification constitutes Subscriber's acceptance of the terms and conditions of this Agreement as modified.

Shahdadi and his team saw the consumers of Tumblr's EULA as "entrepreneurs, inventors, [and] creators."123 The mission of the general counsel's office was to find "the right thing to do" and then "advocate for that, but we also give our users a way for them to express how they feel if they . . . want to." 124 Indeed, both Shahdadi and Karp report that changing the terms to make them user-friendly was a "basic moral imperative," in part because the site was "very focused on creators." 125 They generated terms through an iterative process:

[W]e expected [the users] to read the TOS (and interrogate us on any changes that were suspect). Part of that process was previewing TOS and policy changes and asking for feedback before launching them-which I personally responded to (and it was good feedback). In general we had established

121 Jenna Matecki, Episode 029: Ari Shahdadi on Measuring Success through Impact 33:56-34:09 (Notes on Doing Podcast, Apr 18, 2016), online at http://notesondoing.com/ 029-ari-shahdadi/ (visited Feb 25, 2018) (Perma archive unavailable).

122 Terms of Service (Tumblr, Mar 3, 2010), archived at http://perma.cc/MK7P-XHUD.

123 Randy Milch, GC at Tumblr: Legal Issues Faced by the Digital Publishing Platform 29:02-29:33 (In-House Legal Podcast, Aug 19, 2015), online at http://legaltalknet work.com/podcasts/in-house-legal/2015/08/gc-tumblr-legal-issues-faced-digital-publishing platform/ (visited Mar 31, 2018) (Perma archive unavailable).

124 Id.

125 Email from Ari Shahdadi, 5:45 pm (cited in note 100). 
a relationship of trust between company and user in a number of ways and the TOS \& policies were the written instantiation of that trust. I'd liken it to basic institution-building, something companies are usually awful at. This is why I didn't, e.g., include one of those stupid class-action waivers or a mandatory arb[itration] clause even though they were considered "legal innovations" by the second update I did to the documents.

It's the difference between "corporate social responsibility" as BS marketing and actually caring about your users/ customers. ${ }^{126}$

Tumblr's process was curated at the highest levels of the firm. Shahdadi drafted the terms (with the help of law professor Eric Goldman), and Karp annotated them. ${ }^{127}$

Tumblr's revised TOS are notable for their translations of legal terms. For example, the service, as is typical, mandates: "No individual under the age of thirteen (13) may use the Services, provide any personal information to Tumblr, or otherwise submit personal information through the Services."128 Under that prohibition, in a shaded box, Tumblr helpfully glosses:

Figure 2: Tumblr TOS: Age Prohibition (2016) ${ }^{129}$

You have to be at least 13 years old to use Tumblr. We're serious: it's a hard rule, based on U.S. federal and state legislation. "But I'm, like, 12.9 years old!" you plead. Nope, sorry. If you're younger than 13, don't use Tumblr. Ask your parents for a Playstation 4, or try books.

Similarly, Tumblr provides a precisely worded obligation with multiple different examples of how users can behave maliciously with respect to the service, coupled with a shaded explanation:

126 Email from Ari Shahdadi, 3:08 pm (cited in note 99). See also Ammori, 127 Harv L Rev at 2273 (cited in note 32) (describing Shahdadi's willingness to send an email to every user who commented on the proposed changes to the TOS).

127 See Email from Ari Shahdadi, 3:08 pm (cited in note 99) (“[W]e went in fully knowing the risk that a court would integrate [the annotations] with the document.").

128 Terms of Service (Sept 8, 2016) (“Tumblr TOS, 2016"), archived at http://perma.cc/ D666-4U8G.

129 Id. 
Figure 3: TumblR TOS: MALiCIOUs BeHAVIOR (2016) ${ }^{130}$

You may not, without express prior written permission, do any of the following while accessing or using the Services: (a) tamper with, or use non-public areas of the Services, or the computer or delivery systems of Tumblr and/or its service providers; (b) probe, scan, or test any system or network (particularly for vulnerabilities), or otherwise attempt to breach or circumvent any security or authentication measures; (c) access or search or attempt to access or search the Services by any means (automated or otherwise) other than through our currently available, published interfaces that are provided by Tumblr (and only pursuant to those terms and conditions) or unless permitted by Tumblr's robots.txt file or other robot exclusion mechanisms; (d) scrape the Services, and particularly scrape Content (as defined below) from the Services; (e) use the Services to send altered, deceptive, or false sourceidentifying information, including without limitation by forging TCP-IP packet headers or email headers; or (f) interfere with, or disrupt, (or attempt to do so), the access of any Subscriber, host or network, including, without limitation, by sending a virus to, spamming, or overloading the Services, or by scripted use of the Services in such a manner as to interfere with or create an undue burden on the Services.

Don't do bad things to Tumblr or to other users. Some particularly egregious examples of "bad things" are listed in this section.

Like the platform precatory terms I described earlier, Tumblr insists that "[y]ou agree to provide Tumblr with accurate, complete, and updated registration information, particularly your email address." ${ }^{131}$ But unlike them, Tumblr then justifies the injunction in another shaded paragraph:

\section{FIgURE 4: TUMBLR TOS: EMAIL WARNING (2016)132}

It's really important that the email address associated with your Tumblr account is accurate and up-to-date. If you ever forget your password - or worse, fall victim to a malicious phishing attack - a working email address is often the only way for us to recover your account.

After the new terms rolled out, Shahdadi celebrated the response to them:

[I don't have quantitative] data but I know they were readpeople were turning them into memes when we launched them. We had a bunch of "fake news" misinterpretations of the terms as well, but our own users fought those off because

\footnotetext{
$130 \mathrm{Id}$.

131 Id.

132 Tumblr TOS, 2016 (cited in note 128).
} 
they knew we had their backs. We also forced a click-through in a pop-up or lightbox when we did the update to make sure people at least knew the terms were being updated. ${ }^{133}$

Shahdadi claims that the site made the updated terms conspicuous "to genuinely make sure people saw them-but it also ended up being great marketing." ${ }^{134} \mathrm{He}$ believes that user-friendly terms on the margins produce few real legal risks. ("I took the indemnification provision out-who the heck ever seeks indemnity from a user? It would tank the business.") ${ }^{135}$ At the same time, "it built real trust in the company and company management." 136 But these cost-benefit calculations were, in Shahdadi's view, secondary to the firm's motivation, which was intrinsic: "because we care(d)." 137

Shahdadi also suggests that the business case for friendly and precatory contracts is not obvious for all firms. Though being user-friendly "is still surely a net positive," the advantages to being able to exploit consumers' data through contract terms are also undeniable: they make the "marginal consideration [of userfriendliness] worthless as it is incredibly hard to build and maintain ... one of these [social media] platform businesses at this point [outside of Google/Apple/Facebook's orbit]." 138

\section{B. Kickstarter: Reflecting Its Values}

Kickstarter is a well-known crowdfunding platform that allows backers to support creators' projects by pledging money to their campaigns in exchange for rewards. ${ }^{139}$ Kickstarter reincorporated as a public benefit corporation under Delaware law in 2016. ${ }^{140}$ Its terms were last revised in 2014, as a part of a project to make the entire site more transparent and easy to access. ${ }^{141}$

133 Email from Ari Shahdadi, 3:08 pm (cited in note 99).

134 Email from Ari Shahdadi, 5:45 pm (cited in note 100).

135 Id.

136 Id.

137 Id.

138 Email from Ari Shahdadi, 5:45 pm (cited in note 100).

139 See Our Mission Is to Help Bring Creative Projects to Life (Kickstarter, 2018), archived at http://perma.cc/R7CR-RTKE.

140 Yancey Strickler, Perry Chen, and Charles Adler, Kickstarter Is Now a Benefit Corporation (Kickstarter Blog, Sept 21, 2015), archived at http://perma.cc/54NC-2TM4 (announcing Kickstarter's incorporation as a public benefit corporation and explaining that "Benefit Corporations are for-profit companies that are obligated to consider the impact of their decisions on society, not only shareholders").

141 Interview with Michal Rosenn (cited in note 101). 
Indeed, Kickstarter's public benefit corporation charter now explicitly requires the firm to operate in a way that "reflect[s] its values" and, further, mandates that its "terms of use and privacy policies will be clear, fair, and transparent. Kickstarter will not cover every possible future contingency, or claim rights and powers just because it can or because doing so is industry standard." 142

As a part of the term revision process, Kickstarter's general counsel, Michal Rosenn, asked an intern to distinguish, in the firm's existing (and standard) terms and conditions, the content that was necessary and core to the company's needs from the additional detritus. Rosenn deliberately decided to pare down the terms while not asserting protections that added little business value-forced arbitration and class action waivers, for instancein part because they seemed like an overreach of power. ${ }^{143}$

Rosenn and a nonlawyer then worked to redraft the existing terms to make them clear and jargon free. They had seen Tumblr's terms of use (and indeed Kickstarter is a part of the same small community of New York-based startups, originally funded by the same venture firm, that use the same outside counsel). ${ }^{144}$ Like Tumblr, Kickstarter created simple, easy-to-read summaries of each section of its terms of use and framed them in bright blue boxes at the beginning of each section. It begins:

142 Charter (Kickstarter, 2018), archived at http://perma.cc/PJQ3-PH3B. Rosenn, noting that the charter postdated the revision, suggested that the former's language reflected the firm's motivation and attitude during the reform process. Interview with Michal Rosenn (cited in note 101).

143 In fact, the terms of use operative from 2012 to 2014 did not contain an arbitration clause, though they did contain a choice of forum clause (New York). Terms of Use (Kickstarter, Oct 2012) ("Kickstarter Terms of Use, 2012"), archived at http://perma.cc/PRU5-NRH9.

144 Interview with Hissan Bajwa (cited in note 103). 
FiguRE 5: KiCKSTARTER TERMS OF USE: SumMARY (2014)

This page explains our terms of use. When you use Kickstarter, you're agreeing to all the rules on this page. Some of them need to be expressed in legal language, but we've done our best to offer you clear and simple explanations of what everything means - hence the brief summaries in these blue boxes. The summaries, for the record, are not part of the official legal terms.

Like many sites, for example, Kickstarter requires users to avoid bad behavior. But its Dos and Don'ts section begins, again, with a blue box that contains the following text: "This section is a list of things you probably already know you shouldn't do-lie, break laws, abuse people, steal data, hack other people's computers, and so on. Please behave yourself. Don't do this stuff." 146

Rosenn reports that the translation provided reputational benefits for Kickstarter as well as an improved relationship with users. ${ }^{147}$ The major substantive change in the terms clarified the responsibilities and expectations of creators and backers when it comes to funding projects: the old (buried) language inaccurately overpromised refunds, and Kickstarter wanted to better reflect the practices and expectations around funding on the site. ${ }^{148}$

Given those goals, it's helpful to compare the old and the new versions of the same provision. First, the operative terms as they existed from 2012 through 2014:

145 Terms of Use (Kickstarter, Oct 19, 2014) ("Kickstarter Terms of Use, 2014"), archived at http://perma.cc/V98K-8U7R.

146 Id.

147 Interview with Michal Rosenn (cited in note 101).

148 See Sarah Perez, Kickstarter Updates Terms of Use Section Related to Failed Projects (Techcrunch, Sept 19, 2014), archived at http://perma.cc/MZ76-BKKD; Casey Johnston, Kickstarter Lays Down New Rules for When a Project Fails (ArsTechnica, Sept 21, 2014), archived at http://perma.cc/PHH2-3XVH. 


\section{FigURE 6: KICKSTARTER TERMS OF USE: OPERATIVE TERMS $(2012-2014)^{149}$}

\footnotetext{
Projects: Fundraising and Commerce

Kickstarter is a platform where Project Creators run campaigns to fund creative projects by offering rewards to raise money from. Backers. By creating a fundraising campaign on Kickstarter, you as the Project Creator are offering the public the opportunity to enter into a contract with you. By backing a fundraising campaign on Kickstarter, you as the Backer accept that offer and the contract between Backer and Project Creator is formed. Kickstarter is not a party to that agreement between the Backer and Project Creator. All dealings are solely between Users.

By backing or creating a fundraising campaign on Kickstarter, you agree to be bound by this entire Agreement, including the following terms:

- Backers agree to provide their payment information at the time they pledge to a campaign. The payment will be collected at or after the campaign deadline and only if the amount of money pledged as of the deadline is at least equal to the fundraising goal. The amount Backers pledge is the amount they will be charged.

- Backers consent to Kickstarter and its payments partners authorizing or reserving a charge on their payment card or other payment method for any amount up to the full pledge at any time between the pledge and collection of the funds.

- Backers agree to have sufficient funds or credit available at the campaign deadline to ensure that the pledge will be collectible.

- Backers may increase, decrease, or cancel their pledge at any time during the fundraising campaign, except that they may not cancel or reduce their pledge if the campaign is in its final 24 hours and the cancellation or reduction would drop the campaign below its goal.

- The Estimated Delivery Date listed on each reward is not a promise to fulfill by that date, but is merely an estimate of when the Project Creator hopes to fulfill by.

- Project Creators agree to make a good faith attempt to fulfill each reward by its Estimated Delivery Date.

- For all campaigns, Kickstarter gives to the Project Creator each Backer's User ID and pledge amount. For successful campaigns, Kickstarter additionally gives to the Project Creator each Backer's name and email.

- For some rewards, the Project Creator needs further information from Backers, such as a mailing address or t-shirt size, to enable the Project Creator to deliver the rewards. The Project Creator shall request the information directly from Backers at some point after the fundraising campaign is successful. To receive the reward, Backers agree to provide the requested information to the Project Creator within a reasonable amount of time.

- Kickstarter does not offer refunds. A Project Creator is not required to grant a Backer's request for a refund unless the Project Creator is unable or unwilling to fulfill the reward.

- Project Creators are required to fulfill all rewards of their successful fundraising campaigns or refund any Backer whose reward they do not or cannot fulfill.

- Project Creators may cancel or refund a Backer's pledge at any time and for any reason, and if they do so, are not required to fulfill the reward.

- Because of occasional failures of payments from Backers, Kickstarter cannot guarantee the receipt by Project Creators of the amount pledged minus fees.

- Kickstarter and its payments partners will remove their fees before transmitting proceeds of a campaign. Fees may vary depending on region and other factors.

- Kickstarter reserves the right to cancel a pledge at any time and for any reason.

- Kickstarter reserves the right to reject, cancel, interrupt, remove, or suspend a campaign at any time and for any reason. Kickstarter is not liable for any damages as a result of any of those actions. Kickstarter's policy is not to comment on the reasons for any of those actions.

- Project Creators should not take any action in reliance on having their project posted on the Site or having any of the money pledged until they have the ability to withdraw and spend the money. There may be a delay between the end of a successful fundraising campaign and access to the funds.

Kickstarter is not liable for any damages or loss incurred related to rewards or any other use of the Service. Kickstarter is under no obligation to become involved in disputes between any Users, or between Users and any third party arising in connection with the use of the Service. This includes, but is not limited to, delivery of goods and services, and any other terms, conditions, warranties, or representations associated with campaigns on the Site. Kickstarter does not oversee the performance or punctuality of projects. The Company does not endorse any User Submissions. You release Kickstarter, its officers, employees, agents, and successors in rights from claims, damages, and demands of every kind, known or unknown, suspected or unsuspected, disclosed or undisclosed, arising out of or in any way related to such disputes and the Service.
}

These terms leave significant ambiguity about what happens if projects fail. Talk of "good faith attempt" and "Project Creators

149 Kickstarter Terms of Use, 2012 (cited in note 143). 
are required to ... refund any Backer" contrasts with disclaimers that "Kickstarter does not offer refunds."150 The revised terms (as of 2014), by contrast, break out the responsibilities of backers and creators. Here is the language on backers (which is, for our purposes, key):

\section{FIGURE 7: KICKSTARTER TERMS OF USE: BACKERS (2014)151}

\section{How Funding Works}

This section goes over the details of backing and creating projects - things like how money gets collected, whether pledges can be changed or canceled, and how creators can contact backers to provide rewards.

These are the terms that apply when you're backing a project:

- You're only charged if the project reaches its fundraising goal. You'll provide your payment information when you pledge, but you won't be charged. Your payment will only be collected if, at the time of the project's funding deadline, the project has reached its fundraising goal. The exact amount you pledged is the amount Kickstarter will collect. If the campaign hasn't reached its fundraising goal, you won't be charged, no funds will be collected, and no money will change hands.

- In some cases we'll reserve the charge on your card. Kickstarter and its payment partners may authorize or reserve a charge on your credit card (or whatever payment method you use) for any amount up to the full pledge, at any time between the pledge and the collection of funds.

- You can change or cancel your pledge at any time before the project's funding deadline (with one exception). You can increase, decrease, or cancel your pledge at any time during the campaign, with one exception. During the last 24 hours of the campaign, you can't decrease or cancel your pledge without contacting customer support first - if that action would drop the project below its funding goal. Once the project has been funded, you can only cancel or change your pledge by making special arrangements directly with the creator.

- The Estimated Delivery Date is the creator's estimate. The date listed on each reward is the creator's estimate of when they will provide the reward - not a guarantee to fulfill by that date. The schedule may change as the creator works on the project. We ask creators to think carefully, set a date they feel confident they can work toward, and communicate with backers about any changes.

- The creator may need to send you questions about your reward. To deliver rewards, the creator might need information from you, like your mailing address or t-shirt size. They'll request that information after the campaign has succeeded. To receive the reward, you'll need to provide the information in a reasonable amount of time. Creators should not ask for personal information that is not necessary to provide your reward, and should never request sensitive personal information such as your Social Security number or payment information. Contact us at support@kickstarter.com if you receive a request for information that seems inappropriate or excessive.

- Kickstarter doesn't offer refunds. Responsibility for finishing a project lies entirely with the project creator. Kickstarter doesn't hold funds on creators' behalf, cannot guarantee creators' work, and does not offer refunds.

$150 \mathrm{Id}$.

151 Kickstarter Terms of Use, 2014 (cited in note 145). 
The revision makes much clearer what rights are reserved: the language is cleaner and the font easier to parse. It's consequently not implausible to believe that (according to Rosenn) users sent positive feedback about the change, and Kickstarter has seen fewer questions from users as well. ${ }^{152}$ Moreover, backers, who communicate with creators, rely on and cite the terms of use frequently, suggesting that they have real uptake.153

\section{Etsy: Handcrafted Terms}

A third site is Etsy, also a community for which user buy-in is crucial to the business model. Etsy, like Kickstarter, decided to translate existing terms of use that were "just as generic and ugly as every other generic terms of service out there." ${ }^{154}$ Indeed, they began with a dreaded block of ALLCAPS text:

FIGURE 8: ETSY TERMS OF USE: INTRODUCTION (2013)155

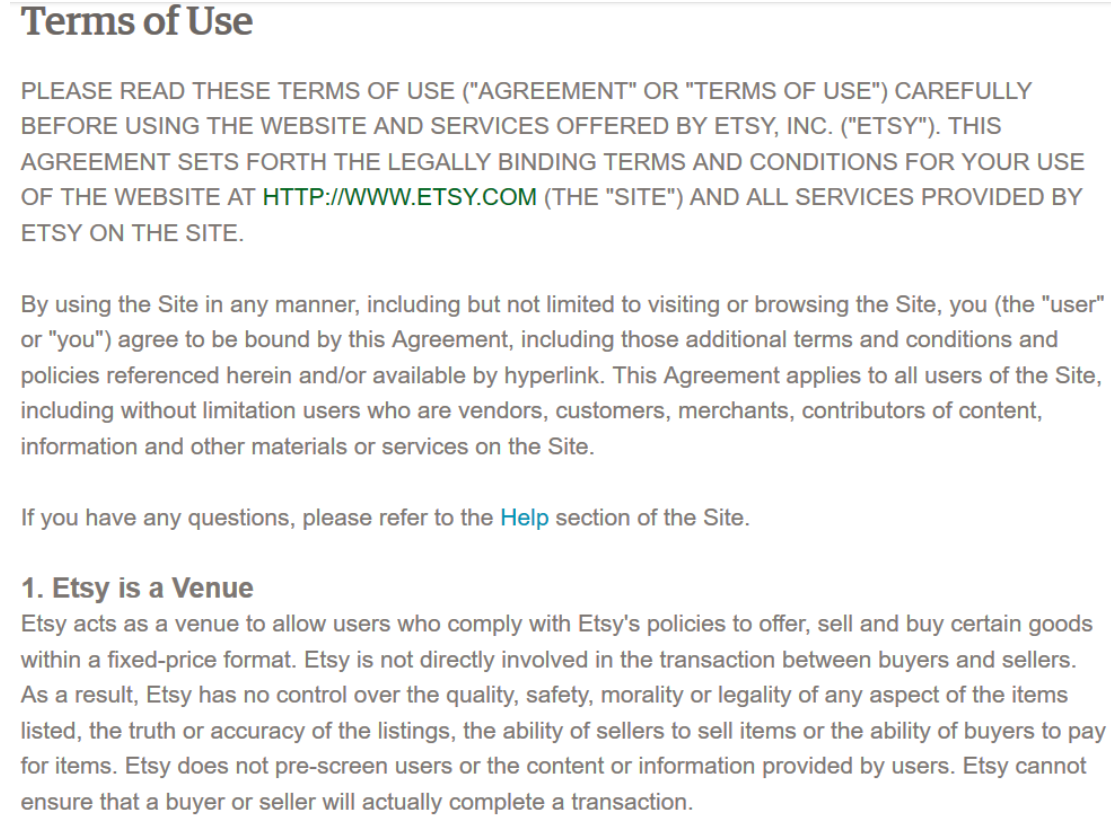

152 Interview with Michal Rosenn (cited in note 101).

153 Id.

154 Interview with Hissan Bajwa (cited in note 103). Bajwa was previously senior counsel at Etsy and the founder and CEO of SpotlessCity.

155 Terms of Use (Etsy, Nov 15, 2013) (“Etsy Terms of Use, 2013"), archived at http://perma.cc/P8US-EW25. 
The change was initiated by a lawyer at the company, Hissan Bajwa (who is now general counsel at another startup). Bajwa noted that the existing terms were dissonant with the mission and look of the rest of Etsy's trade dress:

We use the word handcrafted a lot... [A]ll these other teams are spending all this time making their pieces of the company - their turf-look and feel and reflect who we believe we are as a company.... We the legal team are looking like robot lawyers drafting all these legalistic documents that were a nightmare for our community members to work off of. That's where it came from. ${ }^{156}$

Bajwa, with the permission of the firm's then-general counsel, began by working on the key document, the terms of use. $\mathrm{He}$ decided to "[t]ear it up and start over." 157 But because of the relationship of that document to other contracts, the project quickly expanded. He joined with Bonnie Broeren, who heads Etsy's policy team. Their first goal was to create a unique style guide on how to write its terms and conditions. The objective of that guide was (according to the people who worked on it) to "write policies that are enforceable from a legal perspective, but still human and accessible from a member perspective." 158 An entire section of that guide was dedicated to voice, with instructions on how to write legal terms. To create the guide, Etsy's lawyers worked with "product, engineering and design teams to see what would be possible." 159 The resulting product is a balance of text on the page and headings that had an "impactful presence on the page." 160

As Bajwa pointed out, it's rare for lawyers to have access to engineering resources. In Etsy's case, the resources were fortuitously available:

[The] internal tools team was working [at that very time] on improving our blog and our education content. We thought hold on a second, you are making the seller handbook look and

156 Interview with Hissan Bajwa (cited in note 103).

157 Id.

158 Email from Bonnie Broeren, Head of Policy, Etsy, to David A. Hoffman (Mar 27, 2017, 11:09 am EDT) ("Email from Bonnie Broeren, 11:09 am") (on file with author); Interview with Hissan Bajwa (cited in note 103) ("We came up with this style guide or lexicon so that [the house rules] will be treated as a unit, . . . in the same voice.").

159 Email from Bonnie Broeren, 11:09 am (cited in note 158).

$160 \mathrm{Id}$. 
feel better. Why don't we piggyback on that work and give us a little bit of custom design and graphics? . . . Once [we] frame[d] it as this is very important to our customer service team to reduce their workload, it is hard to argue against it. ${ }^{161}$

The joint team unified the various policies into a single integrated system: Etsy's "house rules."162 Today, those house rules have a distinctive look and feel. Section and paragraph headers are in plain and clear English: "Be honest with us," "Let's be clear about our relationship," "Rights You Grant Etsy," and "Don't Steal Our Stuff." 163 And with respect to particular provisions, Etsy explains why it needs the rights it does, particularly the intellectual property rights it takes. ${ }^{164}$

Thus, compare the pre- and postlicensing rules. The prerevision section starts with a negative ("does not claim ownership") and then provides a lengthy license description, with an embedded link to a privacy policy:

\section{Figure 9: ETsY TERMS OF UsE: LICENSE DESCRIPTION (2013)165}

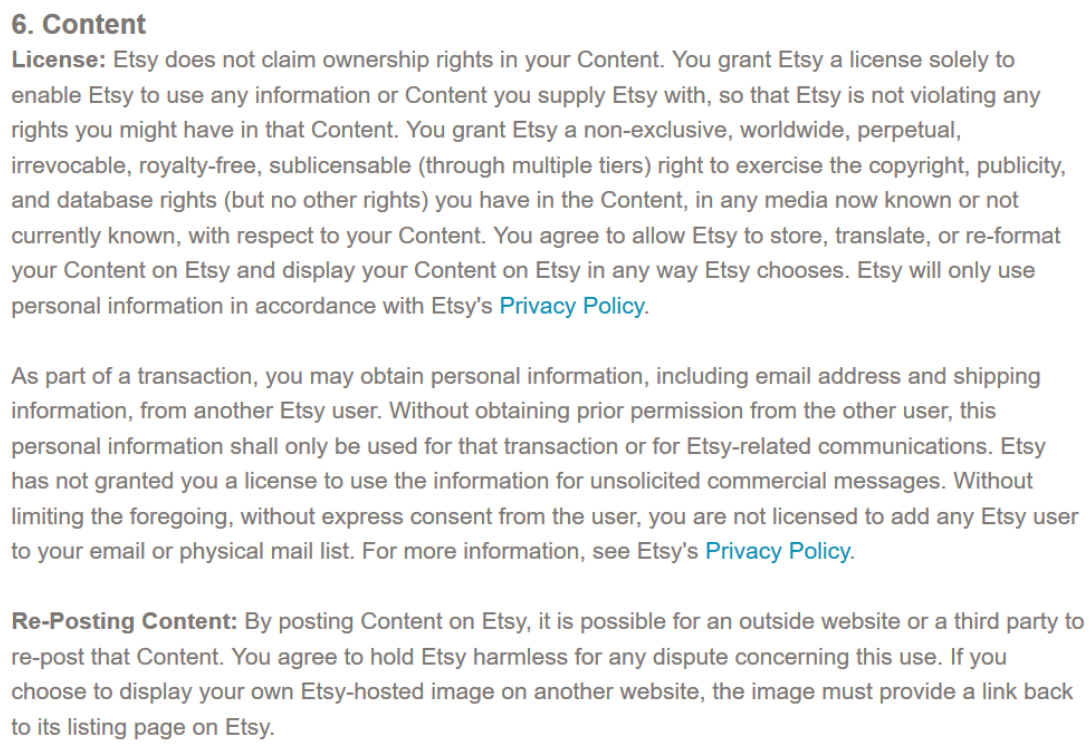

161 Interview with Hissan Bajwa (cited in note 103).

162 Terms of Use (Etsy, Jan 2, 2018) ("Etsy Terms of Use, 2018"), archived at http://perma.cc/L53G-HHQ2.

$163 \mathrm{Id}$.

164 See id.

165 Etsy Terms of Use, 2013 (cited in note 155). 
The same section postrevision is more colloquial, and it starts with affirmative claims ("[c]ontent that you post using our Services is your content") and concrete examples. ${ }^{166}$ It refers to norms of behavior (responsibility) rather than exclusively to legal rules. And, notably, it first provides a nonlegal version of the rules, then a legal version, and then a justification. The result is a set of rights that aren't substantively different but that are more clearly explained:

\section{FIGURE 10: ETSY TERMS OF UsE (REVISED) ${ }^{167}$}

\section{Your Content}

Content that you post using our Services is your content (so let's refer to it as "Your Content"). We don't make any claim to it. That includes anything you post using our Services (like shop names, profile pictures, listing photos, listing descriptions, reviews, comments, videos, usernames, etc.).

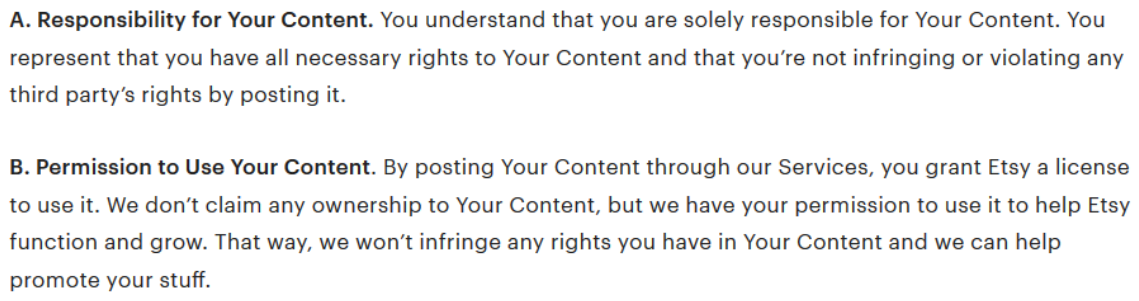

B. Permission to Use Your Content. By posting Your Content through our Services, you grant Etsy a license to use it. We don't claim any ownership to Your Content, but we have your permission to use it to help Etsy function and grow. That way, we won't infringe any rights you have in Your Content and we can help promote your stuff.

C. Rights You Grant Etsy. (Here's the legalese version of the last section). By posting Your Content, you grant Etsy a non-exclusive, worldwide, royalty-free, irrevocable, sub-licensable, perpetual license to use, display, edit, modify, reproduce, distribute, store, and prepare derivative works of Your Content. This allows us to provide the Services and to promote Etsy, your Etsy shop, or the Services in general, in any formats and through any channels, including across any Etsy Services, our partners, or third-party website or advertising medium. You agree not to assert any moral rights or rights of publicity against us for using Your Content. You also recognize our legitimate interest in using it, in accordance with this license, to the extent Your Content contains any personal information.

That sounds like a lot, but it's necessary for us to keep Etsy going. Consider these examples: if you upload a photo of a listing on your Etsy shop, first, we have permission to display it to buyers, and second, we can resize it so it looks good to a buyer using our mobile app; if you post a description in English, we can translate it into French so a buyer in Paris can learn the story behind your item; and if you post a beautiful photo of your latest handmade necklace, we can feature it on our homepage, in one of our blogs or even on a billboard to help promote your business and Etsy's.

166 Etsy Terms of Use, 2018 (cited in note 162).

167 Id. 
This sense of translation is made more explicit by actual illustrations of the terms. For example, Etsy demonstrates the requirement that sellers list handmade items for sale with the following illustration:

\section{FIGURE 11: ETSY ILLUSTRATION168}
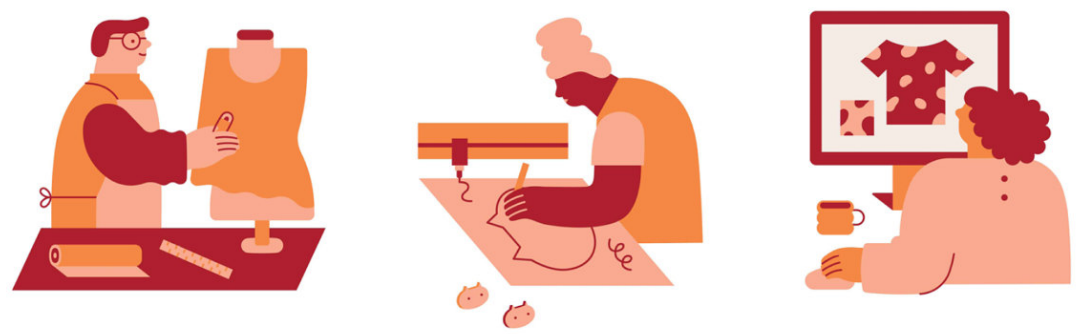

Etsy tested these changes in two ways. It created different versions of the policies with a tool called "Etsy Impressions," which showed sellers particular policies and asked them to highlight sections and give the firm feedback.169 It also ran focus groups with sellers and invited feedback on the changed policies. In so doing, the team proposed to "make sure the people who will be bound by our policies actually understand them." 170

After the terms rolled out, the policy team measured their success by talking to support teams to see if particular provisions were creating friction or resolving it, by monitoring user communication with each other, and by looking at how Etsy's terms were described in the press. ${ }^{171}$ Broeren, cautioning that Etsy's support teams still field complaints and concerns from users, noted:

We did ... see our members positively discussing our policies in our forums, mentioning that they trusted us more than some of our competitors as a result of our easy-to-read policies. We also saw some positive press coverage. Regarding our customer support teams, I would say that incorporating

168 Handmade Policy (Etsy, Feb 22, 2017), archived at http://perma.cc/4642-HHL4. Etsy hoped that "fun illustrations" would "clarify what we were saying in the accompanying text." Email from Bonnie Broeren, 11:09 am (cited in note 158).

169 Email from Bonnie Broeren, 11:09 am (cited in note 158).

170 Id.

171 See id. 
their perspectives is critical to our success as we continue to tweak our policies. They are usually on the front lines of any member dissatisfaction. ${ }^{172}$

And, according to Bajwa, though it is hard to articulate a monetary return for the revision, the site's users appeared less confused and more likely to rely on their own reading of the terms to guide conduct, and the internal customer support workers were less frustrated with the legal department as a result. ${ }^{173}$

\section{Airbnb: Solving a Public Relations Crisis}

Airbnb, the short-term rental site, had a problem. Three researchers had shown that guest applications with distinctively African American names were less likely to be accepted by hosts, and they argued that the platform's design facilitated that outcome. ${ }^{174}$ Rob Chesnut, in his second week as general counsel of the company, was quickly put on his back foot: having not anticipated the issue, "we were forced to take it on reactively, [which is] not the ideal way to do it." 175 Chesnut reports that the firm was a bit surprised by the issue because "our founders and company are in [S] an Francisco, [which is] culturally very tolerant." 176 But once the issue "blew up," the firm had to decide what to do. ${ }^{177}$

One option, according to Chesnut, would be the "standard legal approach" as a platform: disclaiming responsibility for renters' behavior. ${ }^{178}$ Instead, the company decided the right option was to declare that "we own this, we want to be better than this. . . . We're not going to be driven by legal issues here. We're going to be driven by what's important to our mission and our community." 179 Chesnut wrote a first draft of an entirely new nondiscrimination policy, carved out of the existing TOS to "call it

172 Email from Bonnie Broeren, Head of Policy, Etsy, to David A. Hoffman (May 26, 2017, 2:22 pm EDT) (“Email from Bonnie Broeren, 2:22 pm") (on file with author).

173 Interview with Hissan Bajwa (cited in note 103).

174 See Benjamin Edelman, Michael Luca, and Dan Svirsky, Racial Discrimination in the Sharing Economy: Evidence from a Field Experiment, 9 Am Econ J: Applied Econ 1, 2-3 (2017).

175 Telephone Interview with Rob Chesnut, General Counsel, Airbnb (Apr 14, 2017) ("Interview with Rob Chesnut") (on file with author).

176 Id.

177 Id.

178 Id.

179 Interview with Rob Chesnut (cited in note 175). 
out." 180 That draft's goal was to "sound authentic and human" rather than lawyerly. ${ }^{181}$

Chesnut sent the draft to two well-known lawyers, Eric Holder (the former US attorney general) and John Relman, a crusading civil rights and housing lawyer, both of whom played a key role in its drafting process. ${ }^{182}$ As Chesnut noted, the two lawyers and their respective teams "each worked on different elements of [the policy].... In the end, we came up with something that is very Airbnb. It's not crafted by lawyers for legal protection." ${ }_{183}$

The policy itself is, indeed, straightforward and written in a clear and accessible style. Unlike the earlier examples I discuss, there are no visual cues or callouts: Chesnut specifically described "an effort to be authentic, but not legalese, but not cute. There was an intentional effort to keep it simple."184 Thus, the terms permit and prohibit behavior, often in the same section:

\section{FigURE 12: AIRBNB NONDISCRIMINATION POLICY185}

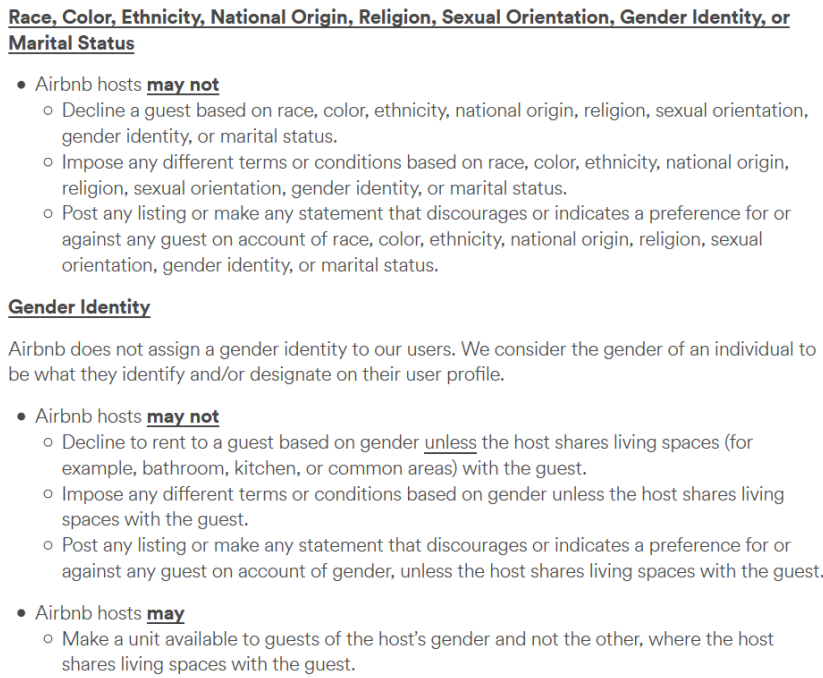

180 Id.

181 Id.

182 Id. For discussion of Holder's role at Airbnb, see David McCabe, Airbnb Enlists Civil Rights Leaders in Discrimination Fight (The Hill, Sept 11, 2016), archived at http://perma.cc/4NKK-XLRS; Brian Chesky, An Update on the Airbnb Anti-Discrimination Review (Airbnb, July 20, 2016), archived at http://perma.cc/J6W3-ADW3.

183 Interview with Rob Chesnut (cited in note 175).

184 Id.

185 Airbnb's Nondiscrimination Policy: Our Commitment to Inclusion and Respect (Airbnb), archived at http://perma.cc/TU6W-ZNLH. 
The policy describes the prohibition on discrimination as an aspect of Airbnb's mission of "bringing the world closer together by fostering meaningful, shared experiences among people from all parts of the world." 186 That is, like the preceding examples, Airbnb deliberately tried to align its brand with the terms to make them more persuasive. Generally speaking, Airbnb's policy rollout resulted in positive press, ${ }^{187}$ though questions remain about whether it in fact alleviates implicit bias. ${ }^{188}$

Chesnut stated that Airbnb did not test out different versions of the policy language, though it had been conducting experiments on different placement of pictures and reviews to encourage user behavior that the firm desires. 189 Though Airbnb required every user to click to agree to the policy, Chesnut acknowledged that the document itself would require continuous monitoring and tweaking through an internal compliance team that surfaces difficult cases and sends them to a committee tasked with refining the rules over time. ${ }^{190}$

There has been a small (under 5 percent) loss in users, which Chesnut attributes to the policy. ${ }^{191}$ But Chesnut admitted that Airbnb has chosen not to conduct its own testing to see if users are discriminating in ways prohibited by the rules. ${ }^{192}$ Though the nondiscrimination policy "is particularly important," looks different from most terms and conditions, and comes "from the heart of the firm," Airbnb's legal response to discrimination appears in some ways to still be reactive. ${ }^{193}$

$186 \mathrm{Id}$.

187 See, for example, Katie Benner, Airbnb Adopts Rules to Fight Discrimination by Its Hosts (NY Times, Sept 8, 2016), online at http://www.nytimes.com/2016/09/09/ technology/airbnb-anti-discrimination-rules.html (visited Apr 1, 2018) (Perma archive unavailable).

188 See Ruomeng Cui, Jun Li, and Dennis J. Zhang, Discrimination with Incomplete Information in the Sharing Economy: Evidence from Field Experiments on Airbnb *25-26 (Dec 8, 2016), archived at http://perma.cc/9QJH-ZMFN (finding evidence that discrimination persists even after the change in terms).

189 Interview with Rob Chesnut (cited in note 175).

190 Id.

191 Id.

192 Id. After I talked with Chesnut, the firm announced that it had reached a settlement with a California regulator to allow the state to conduct such tests on its behalf. See Sam Levin, Airbnb Gives in to Regulator's Demand to Test for Racial Discrimination by Hosts (The Guardian, Apr 27, 2017), archived at http://perma.cc/Q63W-XZEZ.

193 See Interview with Rob Chesnut (cited in note 175). 


\section{E. Bumble: We're Not Tinder}

Finally, let's return to Bumble's funny terms. Bumble is sometimes described as the "feminist Tinder." ${ }_{194}$ But according to Miranda Lerner, a lawyer who was involved with its legal operations at its founding, Bumble sought at its launch to distinguish itself from Tinder. ${ }^{195}$ Lerner (and Wolfe, Bumble's founder) resolved to use the new app's TOS as a differentiation engine.

Lerner worked over several days with a team of younger paralegals and another in-house lawyer. They helped her design a set of terms that felt "young" and "cool."196 The resulting language was sent to a law firm that inserted more formal ("very legal") amendments. ${ }^{197}$ Over a month, that process iterated, with the aim of fusing together the desired tone with the exculpatory language that Bumble's outside counsel required. Indeed, after the "mumbo jumbo" language that introduces this Part, Bumble's terms do in fact revert to legalese:

No failure or delay in exercising any right, power or privilege under the Terms shall operate as a waiver of such right or acceptance of any variation of the Terms and nor shall any single or partial exercise by either party of any right, power or privilege preclude any further exercise of the right or the exercise of any other right, power or privilege. ${ }^{198}$

Were readers more likely to be guided by the framing around this passage? ${ }^{199}$ Lerner, an experienced entrepreneur and counselor, acknowledged that individuals rarely if ever read the terms and conditions of any app-that the terms' real audience (apart from courts) was journalists who might peruse them at the app's

194 Jessica Bennet, With Her Dating App, Women Are in Control (NY Times, Mar 18, 2017), online at http://www.nytimes.com/2017/03/18/fashion/bumble-feminist-dating-app -whitney-wolfe.html (visited Apr 1, 2018) (Perma archive unavailable).

195 Telephone Interview with Miranda Lerner (Jun 9, 2017) ("Interview with Miranda Lerner") (on file with author). Lerner was Head of Legal at Bumble from 2014 through 2016. The app launched during her tenure. Id.

196 Id.

197 Id.

198 Bumble Terms and Conditions (cited in note 111).

199 There is evidence that firms may motivate information acquisition by teasing mysteries. See, for example, Dina Mayzlin and Jiwoong Shin, Uninformative Advertising as an Invitation to Search, 30 Marketing Science 666, 680 (2011) (reporting experimental findings that vague advertising "may increase consumers' likelihood to search for information about the product"). But Bumble did the opposite: it suggested that there was nothing worth learning in the terms. 
launch. That is, Bumble's terms sounded different explicitly because of its branding strategy. ${ }^{200}$

At launch, Bumble's interesting terms may have helped convince journalists that Bumble's product was virtuous. ${ }^{201}$ Lerner pointed out that she knew of no backlash to Bumble's terms and that the product was successfully made distinct. In this way, the terms "[p]rotect[ed the] brand from criticism." 202 At the same time, she argued that the clearly written terms helped the firm "argue [its] case back to [the] customer." ${ }^{203}$ They did so by making the rights themselves clearer (thus leaving less room for interpretative dispute). But also, by injecting humor, Lerner believes that the internal consumer service teams were better able to work out for themselves how to deal with complaints: they could send consumers links to disarming terms rather than "piss[ing] them off with legal language."204

\section{From Options to Relational CONTRACTS OF AdHESION}

What can we learn from these case studies? At the gross level, they provide examples of commercially important platform economy firms that appear to be using mass-market contracts in novel ways. At the very least, those contracts are functioning as extensions of the firms' trade dress: they are more likely to (in Etsy's words) "look and feel and reflect who we believe we are as a company." 205 But according to some of the drafters whose work we've studied, the terms' ambition was larger: to actually enable userparticipants to more easily read, learn from, and work with the terms in resolving disputes with each other. That is, the terms were intended to regulate.

Stepping back from the detail allows us to consider whether these distinctive contracting moments come together to illustrate a new way that some contracts might work in the sharing economy. I believe they do: mass-market contracts govern behavior by

200 See Interview with Miranda Lerner (cited in note 195).

201 I found only a few examples from contemporaneous sources lauding the terms. See, for example, Bumble Buzzes over to Android (Droid Report, Dec 14, 2015), archived at http://perma.cc/NJ5X-2UZ8 ("[Bumble's] Terms and Conditions also indicate that the app will police for abusive, threatening and even defamatory or libelous language and content, as well as content that is 'obscene, pornographic or otherwise may offend human dignity."”).

202 Interview with Miranda Lerner (cited in note 195).

$203 \mathrm{Id}$.

204 Id.

205 Interview with Hissan Bajwa (cited in note 103). 
making adhesive contracts extensions of the firm's brand. These contracts take on relational and discrete attributes. ${ }^{206}$ They are a new phenomenon, what I call "relational contracts of adhesion." 207

What the case studies do not do is provide a general theory explaining why it was these firms that innovated, nor do they do a very good job of predicting when innovation will next arise (if it does). After all, the vast majority of firms, including almost all new economy platform firms, have terms and conditions that are ordinary in form and function. The ultimate goal of this Part is to provide a set of research directions to help us better understand this space. Before doing so, I work to synthesize what we've learned so far.

\section{A. Branding and Mass-Market Contracts}

Most of the case studies started with a problem: a firm with hundreds of thousands or millions of counterparties wanted to affect those individuals' behavior without spending excessive time policing them. In each case, for various reasons, that behavioral problem fell into the lap of a lawyer who decided to adapt a traditionally inert form to a new use. To review:

- Tumblr needed to find a way to embed its terms within the firm's mission of motivating creative production by users. ${ }^{208}$

- Kickstarter needed a way to better channel investor-users when their projects failed and thus reduce reputational blowback to the firm. ${ }^{209}$

206 For a general discussion of relational contracting, see generally Ian R. MacNeil, Relational Contract Theory: Challenges and Queries, 94 Nw U L Rev 877 (2000). See also Charles J. Goetz and Robert E. Scott, Principles of Relational Contracts, 67 Va L Rev 1089, 1091 (1981) ("A contract is relational to the extent that the parties are incapable of reducing important terms of the arrangement to well-defined obligations.").

207 Others, notably Professor Ethan Leib, have suggested that courts should evaluate consumer contracts using relational doctrines. See Ethan J. Lieb, What Is the Relational Theory of Consumer Form Contract?, in Jean Braucher, John Kidwell, and William C. Whitford, eds, Revisiting the Contracts Scholarship of Stewart Macaulay: On the Empirical and the Lyrical 259, 277-80 (Hart 2013). Leib claims that such contracts function as bureaucratic plans that stand not on particular assent to terms but rather "consensual entry into already legitimate relations." Id at 269. He would police terms using the reasonable expectations doctrine. Id at 276 . There is much in this work that I agree with, but of course my focus is different: adhesive contracts that are intended to be read and to influence ex ante behavior.

208 Email from Ari Shahdadi, 5:45 pm (cited in note 100).

209 Interview with Michal Rosenn (cited in note 101). 
- Etsy sought to decrease the likelihood of user behavior that reflected badly on the company because it was leading to friction with Etsy and a loss of the site's ability to be a trusted platform. ${ }^{210}$

- Airbnb needed to reduce user discrimination (or at least be plausibly seen as doing so). ${ }^{211}$

The changes were substantive. For the first three firms, the changes involved abandoning or not taking up remedial limitations and defenses to actions by users; 212 for Airbnb, the changes increased the firm's explicit responsibility for preventing discrimination. ${ }^{213}$ By adding translations, each firm also took on the risk that a court would interpret the translated text differently from the "legal" text. ${ }^{214}$ By avoiding new exculpatory clauses while also adding a layer of uncertainty to the judicial reception of existing terms, all four firms thus increased their formal legal exposure. At the same time, each explicitly worked to avoid legalese and focus on simple, declarative sentences. All except for Airbnb also presented the terms with some playful humor and informality, as well as some visual cues and displays.

Bumble's goals in creating its terms were different. Unlike the previous examples, it did not already have a user base, let alone one that participated as moneymaking participants on a "platform." Rather, Bumble explicitly sought to use contract to distinguish and sharpen its brand. ${ }^{215}$ It did so by projecting youth and informality, perhaps hoping to convince key gatekeeping

210 Email from Bonnie Broeren, 2:22 pm (cited in note 172).

211 Interview with Rob Chesnut (cited in note 175).

212 Etsy's original and modified terms contained an arbitration provision, though the original terms provided for fees to the prevailing party while the modified terms did not. Compare Etsy Terms of Use, 2018 (cited in note 162), with Etsy Terms of Use, 2013 (cited in note 155).

213 See Part III.D.

214 Professor Curtis Anderson, formerly the general counsel of the Match Group (of Match.com and Tinder), told me that Match decided not to follow the Tumblr and Etsy model for terms because of a judgment that a two-track model for terms (and additional illustrations) added legal risk that courts would render important legal protections for the firm unenforceable. Telephone Interview with Curtis Anderson, Associate Teaching Professor, Brigham Young University Law School (Apr 20, 2017) ("Interview with Curtis Anderson") (on file with author).

215 In addition to the Tinder relationship discussed above, I found reference in contemporaneous press to concerns about Bumble's relationship to Badoo, a well-known European social networking and dating site that had been criticized for its privacy practices. See Steve O'Hear, Tinder Rival Bumble Is Majority-Owned by European Dating Behemoth Badoo (TechCrunch, Mar 25, 2016), archived at http://perma.cc/2H3E-945V. To the extent that Bumble wished to signal its distance from that criticism, informal terms would seem to have been a useful approach. 
journalists to write stories that would emphasize that Bumble was a "feminist" dating app. ${ }^{216}$

Thus, one key lesson is that firms are trying to enhance their brands using mass-market contracts. ${ }^{217}$ Indeed, by combining terms, tone, and look, firms can make their legal rules part of the firm's trade dress. ${ }^{218}$ As Shahdadi pointed out, Tumblr's playful approach to terms succeeded in grabbing attention on the web and branding the firm as a humane and trustworthy firm. ${ }^{219}$ At Etsy, it was the incongruence of ordinary terms with the site's brand that motivated the project, ${ }^{220}$ and the team, justifying the new terms, claimed that they "can even provide a competitive advantage over other companies whose terms are more difficult to understand." 221 Airbnb's general counsel noted that its revised policy was "very Airbnb," both aesthetically and in terms of congruence with its mission. ${ }^{222}$

This trade dress-centered understanding of functional terms is not entirely novel. A famous example of cobranding using legal material comes from the online gaming firm Zynga. In the leadup to the firm's initial public offering, it launched a social game through its website that taught users about its privacy policy and linked to reward chits that could be used in related games (like FarmVille).223 That gamification of the privacy rules received very positive coverage as well as laudatory attention in the world of

216 See Interview with Miranda Lerner (cited in note 195).

217 Others have suggested that contracts can serve a branding function, though not in the consumer context. See, for example, Victor Fleischer, The MasterCard IPO: Protecting the Priceless Brand, 12 Harv Negotiation L Rev 137, 153 (2007) (focusing on MasterCard's transactional structuring as a form of brand enhancement); D. Gordon Smith, The "Branding Effect" of Contracts, 12 Harv Negotiation L Rev 189, 195-98 (2007) (discussing the information-conveying function of contracts in the venture capital context). 218 I mean this in the colloquial sense-I'm not sure that the TOS would meet the Lanham Act definition of trade dress, in part because they are functional. See Fair Wind Sailing, Inc v Dempster, 764 F3d 303, 309 (3d Cir 2014) (identifying elements of trade dress infringement, including that the infringing design be "nonfunctional").

219 See, for example, Caroline Moss, Tumblr's Hilarious New Legal Terms of Service Include a Ban on Pretending to Be Benedict Cumberbatch (Business Insider, Jan 30, 2014), online at http://www.businessinsider.com/tumblrs-new-terms-of-service-is-inspiring-and -funny-2014-1 (visited Apr 1, 2018) (Perma archive unavailable). I am not arguing that the motivation for change by Shahdadi was primarily instrumental. I think he held a sincere belief that it was, in fact, the right thing to do. Rather, he was able to justify his motivation in terms that spoke across constituencies.

220 See Interview with Hissan Bajwa (cited in note 103).

221 Email from Bonnie Broeren, 11:09 am (cited in note 158).

222 Interview with Rob Chesnut (cited in note 175).

223 Julie Beck, Zynga Inc.: Game-ification, InsideCounsel 58 (Sept 2012). 
privacy policy. ${ }^{224}$ According to Jay Monahan, the lawyer at Zynga most responsible for the product's rollout, it also had three additional positive attributes. It helped to establish a positive relationship between the firm and the Federal Trade Commission, 225 which had recently released a report on the importance of privacy transparency. ${ }^{226}$ It increased readership of the underlying privacy policies. ${ }^{227}$ And, significantly for our purposes, it aligned with the firm's mission and brand that games could be both entertaining and educational. ${ }^{228}$

As others, notably Professor Danielle Citron, have suggested, firms can enforce their TOS in a way that signals their allegiance to larger social campaigns, ${ }^{229}$ highlighting virtues and thus gaining reputational capital.230 For example, MySpace changed its TOS to ban certain kinds of speech and enforced those bans with aggressive moderation. These efforts helped the firm "by creating market niches and contributing to consumer goodwill." ${ }^{311}$ Others, including Professor Robert Gomulkiewicz, have argued that firms should modulate the tone of their EULAs to "build goodwill with consumers." 232 But the idea that harmonizing the look and feel of terms can help make them functional has yet to be explored.

Understanding how these terms work as extensions of the firm's brand is jarring. There is something odd about the idea that hypermodern sharing economy firms try to advance their hipster credentials with that most antiquated behavioral tool of all: a contract. Indeed, the message can be easily confused: Bumble says, on the one hand, "We're relaxed and hip enough to say that law is bunk," but on the other hand, "Our lawyers insist that you are

224 See, for example, Will Simonds, Getting from PrivacyVille to the Real World of Online Privacy (The Online Privacy Blog, July 8, 2011), archived at http://perma.cc/8ZL7-W6AE (characterizing the gamified privacy policy as "an inspired step in the right direction").

225 Telephone Interview with Jay Monahan (Jan 3, 2018) ("Interview with Jay Monahan") (on file with author).

226 See Federal Trade Commission, Protecting Consumer Privacy in an Era of Rapid Change: A Proposed Framework for Businesses and Policymakers (Dec 2010), archived at http://perma.cc/2X5N-EPXB.

227 Interview with Jay Monahan (cited in note 225).

228 Id.

229 See Danielle Keats Citron, Law's Expressive Value in Combatting Cyber Gender Harassment, 108 Mich L Rev 373, 412-13 (2009).

230 See Citron, Hate Crimes in Cyberspace at 230-31 (cited in note 41).

$231 \mathrm{Id}$ at 229.

232 Gomulkiewicz, 12 Geo Mason L Rev at 696 (cited in note 86). 
bound by bunk." ${ }_{233}$ Airbnb may be seeking to put out a public relations fire by suggesting that it has a better way of communicating with users (though, in reality, it may not actually care if users read the policy). Thus, there is an element of false consciousness here: terms might be gaining user trust, and regulators' approval, through a revision that in fact does little of substance.

This dystopian vision of the sharing economy has been forcefully advanced by Professor Ryan Calo, culminating in his coauthored exposé of Uber's predatory behavior, Taking Economy. ${ }^{234}$ Calo argues that, because firms have the opportunity to learn about users en masse and the motive to exploit their vulnerabilities, we ought to be concerned lest actions that they take couched in the new economy's language of freedom and choice confuse us about the reality of exploitation on the ground. Thus, one way to see the case studies I present is as wolfish firms successfully branding themselves as sheep. ${ }^{235}$

While this story is plausible for some firms, it doesn't really capture the phenomenon at work here. Apart from Bumble, and perhaps Airbnb, each of our case study firms increased its legal exposure to suits by making it harder (on the margins) to exercise defensive clauses. The lawyers I spoke to said that they were comfortable with this trade not only because of the benefits it secured in terms of user buy-in, but also because the change fit with a larger public brand that the firm was eager to extend. And, apart from Bumble, the lawyers pushing the change stressed their internal motivation to do the right thing as an important or motivating factor in the particular sorts of choices that were made.

233 This relates to a point made by Citron about how vague TOS can dilute expressive messages. Citron, Hate Crimes in Cyberspace at 231 (cited in note 41) (explaining that "[t]he more clearly and specifically companies explain those terms and the harms that they want to prevent, the better users will understand what is expected of them").

234 See Ryan Calo, Digital Market Manipulation, 82 Geo Wash L Rev 995, 1018 (2014) ("A firm with the resources and inclination will be in a position to surface and exploit how consumers tend to deviate from rational decisionmaking on a previously unimaginable scale.”); Calo and Rosenblat, 117 Colum L Rev at 1623 (cited in note 8) (arguing that contracting is a way that firms like Uber exploit their drivers).

235 See Brett Frischmann and Evan Selinger, Re-Engineering Humanity ch 4 (Cambridge 2018) (arguing that consumer contracts are shaping preferences in nefarious ways). 


\section{B. The Costs and Consequences of Innovations}

The firms provide different models for producing termsfrom one that was determined by lawyers (Kickstarter, Airbnb, and Bumble), to a collaboration between the general counsel and CEO with informal user feedback (Tumblr), to an interdisciplinary team with regularized user feedback (Etsy). ${ }^{236}$

These different processes reveal how the task of redrafting the fine print can have organizational consequences inside the firm. Revision of terms reveals something about firm culture: as Shahdadi says, "I would never farm this task out-it's core to every company. ... [N] ext time I would be more aggressive and do most of the work myself." ${ }^{237}$ That is, when firms think about how to make precatory fine print functional, they might come to learn things about themselves. This organizing function of disclosure is an important, but understudied, phenomenon. As Professor Peter Swire, explaining the beneficent effects of required financial privacy disclosures, puts it:

I contend that a principal effect of the notices has been to require financial institutions to inspect their own practices. ... In order to draft the notice, many financial institutions undertook an extensive process, often for the first time, to learn just how data is and is not shared between different parts of the organization and with third parties. Based on my extensive discussions with people in the industry, I believe that many institutions discovered practices that they decided, upon deliberation, to change. 238

Arguably, this kind of focusing effect can be socially useful even if it isn't terribly effective at directly changing behavior. The mere fact that the firm has thought about how to write terms that

236 See Interview with Hissan Bajwa (cited in note 103) ("Unlike most or many consumer sites, we have an active community and our sellers are an active community who read every word of this."). See also Gomulkiewicz, 12 Geo Mason L Rev at 700-01 (cited in note 86) (arguing that, in the software industry, lawyers' exclusive role in drafting terms hampers user-friendliness).

237 Email from Ari Shahdadi, 3:08 pm (cited in note 99).

238 Peter P. Swire, The Surprising Virtues of the New Financial Privacy Law, 86 Minn L Rev 1263, 1316 (2002) (contending that disclosure requirements trigger selfexamination by firms). 
tell users not to be obnoxious may influence it to invest more effort in how to prevent corrosive user conduct, leading to innovations in page design. ${ }^{239}$

For example, at Etsy, the revision process required the legal and policy team to talk with a variety of stakeholders within the firm. While the older terms had a "Frankensteinian" aspect, the new ones were designed to be coherent. ${ }^{240}$ Some of the conversations required translation of technical concepts (like the payment and direct checkout system). ${ }^{241}$ Though they got a "gut check" from outside counsel, the inside legal team spent a considerable amount of time trying to coordinate the views of diverse internal audiences and making sure they were on (literally) one page. ${ }^{242}$

One question is whether it is possible to entirely outsource the project of producing functional precatory contracts. As it turns out, a firm called Snapterms tried, between 2011 and 2014, to sell terms with a sense of humor to small businesses with relatively simple consumer sales interfaces. It was marketed extensively, with features on popular websites, as a place where you could get semicustomizable terms for a fixed price. ${ }^{243}$ Over three years the firm sold 2,200 contracts, and around 10 percent of customers paid extra for humorous inserts. ${ }^{244} \mathrm{As}$ an example, consider the site's own description of its services:

Snapterms is a legal service for people who don't want to mortgage their house to hire a traditional law firm. Snapterms, in turn, consists of an elite team of lawyers who have made the career decision to whore ourselves out at bargain basement prices. How do we keep prices so low? Well, we can't really discuss trade secrets, but it involves a giant

239 See Citron, Hate Crimes in Cyberspace at 232 (cited in note 41) (describing the Inter-Parliamentary Task Force on Internet Hate's Anti-Cyberhate Working Group's discussions about "developing guidelines that will help users better understand terms-ofservice requirements").

240 Interview with Hissan Bajwa (cited in note 103).

241 Id.

242 Id. In some ways, Etsy's process followed the model process laid out by Gomulkiewicz for how one might design a user-friendly contract, though there is no evidence that they knew of his work. See Gomulkiewicz, 12 Geo Mason L Rev at 703-05 (cited in note 86) (detailing the model process, which includes using an interdisciplinary team and creating terms that are cohesive, user-friendly, and well designed).

243 See Sarah Perez, SnapTerms: Terms of Service as a Service (TechCrunch, Apr 13, 2012), archived at http://perma.cc/3XXC-KVPT.

244 Telephone Interview with Hansen Tong (Apr 27, 2017) ("Interview with Hansen Tong") (on file with author). Tong was a co-owner of Snapterms and one of the individuals involved with its business operations until it closed for a "pivot" in late 2014. 
mill contraption like in Conan the Barbarian, but with a bunch of lawyers chained to it. ${ }^{245}$

Unlike the in-house examples I discuss, Snapterms did not attempt to actually ensure that its terms were more readable (or read) than the alternative. Though it hired advertising copywriters to create humorous inserts, it did not test its product's readability, or actual reader comprehension, in a scientific way. ${ }^{246}$ Snapterms borrowed some of its ideas for humor and explanatory phrases from other websites and did not attempt to tie its explanations into its clients' brands or identity. ${ }^{247}$ Thus, it is unclear whether outsourcing is a viable solution to the no-reading problem.

These stories show how weak, in the end, are explanations that blame lawyers for failures to innovate around terms. It was lawyers at Kickstarter, Etsy, and Tumblr (among others) who innovated around contracts in their respective firms and solved pressing business problems. They were not uniquely risk-seeking, even though they did come from the same New York-based entrepreneurial law community. ${ }^{248}$ That is, innovation and legal training are not incompatible.

Then why did these firms innovate when others did not? I think the reasons are many but start with a compelling business logic. ${ }^{249}$ Bumble is the clearest case, though its terms are the least innovative. Plainly, it saw informal terms as an inexpensive branding play: the incongruity between legalese and informality was a virtuous signal that the firm was run by real people who could be trusted to behave well—not only with respect to what's

245 Snapterms.com Terms of Service (Snapterms, 2017), archived at http://perma.cc/AHA9-REQN.

246 Obviously, the Snapterms team did monitor client feedback (which was positive) and followed reviews online at places like Reddit to be sure that the market regarded its terms as clear. My point is that it did not design processes to learn about the terms in a more rigorous way. See Interview with Hansen Tong (cited in note 244) (noting that they spent time improving the readability of the indemnification, representations and warranties, and limitations on liability terms).

247 Id (explaining that Snapterms bought legal terms from LegalZoom, hired copywriters to insert humor, and looked to Tumblr in drafting explanatory phrases).

248 Indeed, Etsy, Tumblr, and Kickstarter arose from the same venture capital fund, Union Square Ventures, and share an outside counsel, Gunderson Dettmer. Interview with Hissan Bajwa (cited in note 103).

249 One driver of innovation might be that the firms I studied had relatively simple business models and relatively low risk exposures. Match.com, by contrast, was exposed to a high likelihood of user-generated lawsuits, including for tortious conduct by other users that might be attributed to the firm. Interview with Curtis Anderson (cited in note 214). The audience for Match's terms and conditions was courts and regulators, not primarily consumers. Id. 
disclosed but also how the firm will behave when no one is looking. ${ }^{250}$ A firm that casually refers to law as "mumbo jumbo" may seem like the affable type that is unlikely to sell your information to the nearest data aggregator. Bumble needed to send out that message in part because of the circumstances of its founding: its terms simply could not follow the standard and sterile playbook. ${ }^{251}$

The other case examples provide a more complex set of motivations. Because their customers are often also merchants, who often build businesses and brands on the platform, the studied firms have users with a vested interest in the content of the terms and who care greatly about the performance-shaping rules that they contain. Someone who buys on Etsy might also become someone who sells on the site: the "house rules" are addressed to an intensely attentive audience. As Etsy's representative explained to me: "We want our members to trust us, and writing policies that are easy to understand is a big part of earning that trust." 252 Similarly, Kickstarter derives its revenue by being seen as a trusted intermediary between a mass of internet "investors" and a smaller number of firms: the terms of use are the constitutive document, meant to be understood and read by all, as opposed to only those for whom deals go bad. And Tumblr users will often bemoan their exclusion from the community, as hard-built personal brands disappear overnight. ${ }^{253}$

In other words, even old-fashioned, monopolistic lawyers write readable mass contracts (which might also be read) when both firms and their "customers" demand them. But when users (or reporters) aren't motivated to pay attention, firms' incentives to innovate are reduced, and it starts to make more sense to stick with the status quo. ${ }^{254}$ That is, just as in other fields, new entrants

250 For an analogous example of this sort of playing with law in trademark, see Don't Say Velcro (Velcro Brand, Sept 25, 2017), online at http://www.youtube.com/watch?v= rRi8LptvFZY (visited Apr 1, 2018) (Perma archive unavailable).

251 This is in accord with Professor Victor Fleischer's insight about "branding moments" in a corporation's life, when otherwise sterile forms (like a charter) can further its brand. Fleischer, 12 Harv Negotiation L Rev at 151-53 (cited in note 217); Victor Fleischer, Brand New Deal: The Branding Effect of Corporate Deal Structures, 104 Mich L Rev 1581, 1600, 1628 (2006) (explaining that branding moments are most important early in a company's life).

252 Email from Bonnie Broeren, 11:09 am (cited in note 158).

253 See Gavia Baker-Whitelaw, Tumblr Users Panic as Accounts Are Deleted for Copyright Violations (The Daily Dot, Feb 24, 2015), archived at http://perma.cc/CUP5-S25Q.

254 See Claire A. Hill, Why Contracts Are Written in "Legalese", 77 Chi Kent L Rev 59, 78-80 (2001) (highlighting the challenges of changing terms in contracts); Clayton P. Gillette, Lock-In Effects in Law and Norms, 78 BU L Rev 813, 819 (1998) (contrasting the 
and outsiders innovate. Thus, we can see innovation that makes terms more communicative (or at least seem to be more communicative) as akin to innovation in the terms themselves: they result from learning, over time, about the firm's market position and the returns that it will reap from change. ${ }^{255}$

Innovation is expensive; Etsy's lawyers noted that "cost sensitivity" matters here. ${ }^{256}$ Indeed, as Bajwa lamented, the revision process took six months, much of it on nights and weekends carved out from the day-to-day work of being a lawyer for a busy and growing firm. ${ }^{257}$ For most general counsel at most firms, renovating the terms and conditions to make sure that terms that command obedience are understandable simply isn't high on the priority list. Bajwa continued:

Now that I'm GC at a new and much younger startup, when I look at my priorities right now with much fewer resources and a company that is in a much different position, I can't justify devoting time to focusing on the terms of service here. ... Our user base is not interested [in the same way as Etsy's]. If they are legally sound that is fine for now. ${ }^{258}$

This suggests that the market for terms like those I describe might be constrained. Similarly, Kickstarter's Rosenn pointed out that existing terms "get the job done" by mitigating risk. In the hurly burly of the day, with competing demands on a general counsel's time, marginally improving the terms is usually cost prohibitive: it's a "challenging" task to "force yourself outside of the lawyer lens and think about language and policies in a more human way." 259

More generally, general counsel argue that the time spent on terms is quite difficult to justify in a world in which much of what must be contained in terms of use is mandated by law or compelled by solving transnational compliance problems. According

lack of contract innovation with innovation in technology); Henry T. Greely, Contracts as Commodities: The Influence of Secondary Purchasers on the Form of Contracts, 42 Vand L Rev 133, 168 (1989) (comparing the difficulty of innovation in standardized contract terms to trying to change the dominant QWERTY keyboard layout).

255 Davis, 88 NYU L Rev at 108 (cited in note 106) (explaining that innovation results from "learning-by-doing").

256 Email from Bonnie Broeren, 2:17 pm (cited in note 102).

257 Interview with Hissan Bajwa (cited in note 103).

258 Id. See also Gomulkiewicz, 12 Geo Mason L Rev at 701 (cited in note 86) (describing "[l]ack of leadership by [ ] senior management" as a barrier to innovative contract drafting).

259 Interview with Michal Rosenn (cited in note 101). 
to lawyers at the IAC Group (which owns or owned Ask.com, Match.com, Vimeo, and other new economy firms), terms of use are hard to read and complex because they must be: lawyers are trying to solve worldwide compliance issues, responding to evolving business goals and technical modalities, while permitting firms maximum flexibility to maneuver in fields like privacy. Given that "the working assumption is that no one is reading the TOS," it would be a Sisyphean task to spend significant efforts to encourage readership of documents that must, by their nature, be hideously complex. ${ }^{260}$ Michael Cheah, Vimeo's general counsel, lamented: "You can do as much education as you want on terms, people aren't going to sit down and read them." 261

This account, then, suggests that the barrier to innovation isn't lawyers' training or risk aversion—or at least not primarily those factors. Rather, firms innovate and create terms that look functional when it is in their interest to do so. The set of cases in which those conditions hold is not zero, but it might be quite small.

\section{Relational Contracts of Adhesion}

With this account of why and when precatory terms work in hand, we can turn our attention to considering how our case studies fit in the existing taxonomy of contract law and practice. To wildly oversimplify, that taxonomy can be thought of as starting with the nineteenth century's classical contract: a fully negotiated contract between equally situated individuals. From that root came two great branches. The first is the modern commercial contract, marked by negotiation ex ante (at least some of the time), and reputationally determined performance goals and norms. ${ }^{262}$ Such contracts are intended to be read and to govern behavior while the parties' relationship remains intact.

The second branch is the classic consumer contract of adhesion. ${ }^{263}$ Consumer contracts are not negotiated ex ante, are offered on a take-it-or-leave-it basis, and (as I describe) function as discretionary options. ${ }^{264}$ The drafters of such contracts are aware

260 Interview with Ed Ferguson and Michael Cheah (cited in note 83).

261 Id.

262 See text accompanying notes 51-53.

263 For an influential analysis of this type of contract, see Friedrich Kessler, Contracts of Adhesion-Some Thoughts about Freedom of Contract, 43 Colum L Rev 629, 631-32 (1943) (describing the rise of consumer contracts of adhesion).

264 See text accompanying notes 69-70. 
that their terms will be unread by their mass adherents. The audience is ex post-largely for courts and secondarily for aggrieved consumers.

One way to think about the case studies in this Article is that they have taken on attributes of both traditional consumer and commercial contracts. This can be seen along a number of dimensions, as the following table illustrates:

TABle 1: CONTRACT ATtRIBUtes

\begin{tabular}{|c|c|c|c|}
\hline & $\begin{array}{l}\text { Consumer } \\
\text { Contracts }\end{array}$ & $\begin{array}{l}\text { Commercial } \\
\text { Contracts }\end{array}$ & $\begin{array}{l}\text { Platform Case } \\
\text { Studies }\end{array}$ \\
\hline $\begin{array}{l}\text { Individually } \\
\text { negotiated or } \\
\text { adhesive }\end{array}$ & Adhesive & Negotiated & $\begin{array}{l}\text { Some informal } \\
\text { drafting but } \\
\text { then deployed } \\
\text { adhesively }\end{array}$ \\
\hline $\begin{array}{l}\text { Number of } \\
\text { counterparties }\end{array}$ & Millions & A handful & Millions \\
\hline Duration & $\begin{array}{l}\text { Largely one-off } \\
\text { purchases }\end{array}$ & Relationship & Relationship \\
\hline $\begin{array}{l}\text { Reading ex- } \\
\text { pected? }\end{array}$ & No & Yes & Yes \\
\hline $\begin{array}{l}\text { Merchants or } \\
\text { Consumers }\end{array}$ & Merchants & Both & Both \\
\hline $\begin{array}{l}\text { How are terms } \\
\text { usually en- } \\
\text { forced? }\end{array}$ & $\begin{array}{l}\text { Exclusion and ex } \\
\text { post litigation } \\
\text { defenses }\end{array}$ & $\begin{array}{l}\text { Reputational } \\
\text { markets } \rightarrow \text { self- } \\
\text { policing }\end{array}$ & $\begin{array}{l}\text { Exclusion and } \\
\text { internalization }\end{array}$ \\
\hline $\begin{array}{l}\text { Sharing of } \\
\text { benefits and } \\
\text { burdens }\end{array}$ & No & Yes & Yes (in theory) \\
\hline
\end{tabular}

These categories are largely self-explanatory with a few exceptions:

- Merchants or consumers: Categorizing platform counterparties as consumers or merchants may be one of the key legal and political questions of the digital age. It doesn't seem fair to conclude that Etsy's 1.9 million sellers ${ }^{265}$ (for example) are all "merchants" in the same way that firms in traditional consumer contracts are. For one, they may be buyers and sellers of items

265 See About Etsy (Etsy, Sept 31, 2017), archived at http://perma.cc/LE7X-KW9U (describing 1.9 million "active sellers" on the platform). 
simultaneously, and for another, they may be hobbyists or individuals earning their livelihood. This is even truer for Tumblr, which attracts both professionals and those who simply seek to express themselves. Now, obviously, heavy users on each site are probably more like traditional merchants than they are like oneoff consumers, but it's not at all clear that such users were the exclusive audience for the revised tone and feel of terms that I discuss.

- How are terms enforced: Like ordinary consumer contracts, platform terms work in part through exclusion: users are thrown off sites for bad behavior, and terms (filtered through moderators and complaint systems) enable those sanctions to proceed smoothly. But unlike consumer contracts, the evidence I adduce suggests that platform contracts also succeed because at least some of their adherents read them, talk about them, and use them in dealing with one another. That is, the terms become a part of the reputational market on the platform.

- Sharing of benefit and burdens: This is a shorthand way of asking how one-sided the contracts are: Do they grasp each advantage for the drafting party, or do the mass counterparties retain sufficient negotiating power to make the resulting exchanges moderately "fair"? Here, it is difficult to know with precision. I show that firms have forgone some opportunities to exculpate liability and control litigation risk. At the same time, the firms do share some of the benefits of the platform with their users, in that they permit users to monetize their property and do not take ownership in it. Whether platform firms generally are largely benign is outside the scope of this Article, but I return later to the question of just how "fair" their contracts in fact are. ${ }^{266}$

What to make of this mix? A word that came up repeatedly in my conversations with the lawyers who drafted these contracts was relationship. The contracts were intended to embody trust between the firm and its users, to demonstrate that the terms were aligned with the firms' long-term mission, and to encourage users to continue to participate in the platform. ${ }^{267}$ The firms had no desire to sue any of their users for violations of the terms. At most, they wished to weed out from their sites users who were disruptive to the platform's functioning, but otherwise they hoped

266 See notes 283-86 and accompanying text.

267 For an example of a similar practice, see Gillian K. Hadfield, Legal Infrastructure and the New Economy, 8 I/S: J L \& Pol Info Socy 1, 46-47 (2012) (reporting that the CBS general counsel wanted lawyers who could design a "relational structure"). 
to create a set of rules that would be self-policing. ${ }^{268}$ This reads, in many ways, like an attempt to create a classic relational contract, counterpoised to the ordinary discrete consumer contract. 269

As with the traditional description of relational contracting, the governing contracts here are "not designed to create incentives for performance and breach primarily through the prospect of court-imposed monetary damages." 270 Performance is rather governed largely by users internalizing a set of rules created through brand alignment, informality, and interpersonal norms of reciprocity and fairness (thus, Bumble says, "[W]e've worked hard on our creation, so scraping or replicating any part of the App without our prior consent is expressly prohibited"). ${ }^{271}$ As Professor Oliver Hart has explained, reciprocity is a strong norm when the participants clearly understand what they are getting and giving:272 Etsy's need to clarify the intellectual property rights that its platform takes (or doesn't) thus was a crucial part of its reform process.

When soft norms fail, even in relational contracting systems, firms retain the ability to use a heavier hand. Here, our case study firms start their sanctions with rating-based complaint systems, escalate to suasion by site moderators, and finally exclude bad users from the marketplace entirely. But those systems can be overstrained: as the case studies show, firms innovated here in part because their customer service representatives needed a break from noncompliant users, who needed to be better convinced that they were in a relationship of trust and reciprocity. In this way, we can see the relational contracts here as solving a

268 An analogy is to online dispute resolution systems, like that of Wikipedia, which seek to weed out problematic users but otherwise motivate productive editors to continue to dispute (and generate content for the platform). See David A. Hoffman and Salil K. Mehra, Wikitruth through Wikiorder, 59 Emory L J 151, 170-74 (2009) (exploring Wikipedia's dispute resolution system).

269 For an analysis of this distinction, see Ian R. Macneil, The New Social Contract: An Inquiry into Modern Contractual Relations 10 (Yale 1980) (distinguishing discrete contracts from relational ones). For an early, aspirational version of relational contracting in digital spaces, see Andrea M. Matwyshyn, Mutually Assured Protection: Toward Development of Relational Internet Data Security and Privacy Contracting Norms, in Anupam Chander, Lauren Gelman, and Margaret Jane Radin, eds, Securing Privacy in the Internet Age 73, 8182 (Stanford 2008). But see Bar-Gill and Davis, 84 S Cal L Rev at 35 (cited in note 7) (noting that consumer contracts are sometimes designed to govern long-term relationships).

270 Lisa Bernstein, Beyond Relational Contracts: Social Capital and Network Governance in Procurement Contracts, 7 J Legal Analysis 561, 562 (2015).

271 Bumble Terms and Conditions (cited in note 111).

272 See Oliver Hart, Economica Coase Lecture: Reference Points and the Theory of the Firm, 75 Economica 404, 407 (2008). 
business problem: they needed to keep users engaged, on task, and willing to contribute to a larger platform economy.

But platform users aren't ordinary relational contracting counterparties. ${ }^{273}$ Etsy and Tumblr's creators are heterogeneous and myriad: ordinary norms and reputational sanctions alone can only weakly police behavior. ${ }^{274}$ From the case studies, it seems clear that one important way that these contracting systems work is through consumer service teams, who use the terms themselves to remind users of the rules. This is not the traditional relational contracting setting in which the rules are (at best) the beginning of the conversation. ${ }^{275}$ Platform sites are in a repeated, socially rich, virtual relationship with each of their users. ${ }^{276}$

Moreover, the contracts here, though focus-grouped ex ante, are formally adhesive: individual Etsy or Kickstarter users simply cannot negotiate their own deals with each other or with the site. That's true in part because terms of use are mass agreements, binding not hundreds on a local or regional bourse but millions, worldwide, on the internet. It would be inconceivable for platform firms to come to separate deals with each of their users, or even talk about the deals in detail with a fraction of them. Conventionally, "[c]ontracts of adhesion and relational contracts are in some ways opposite to each other," 277 making even the term "relational contracts of adhesion" a difficult one.

273 For analyses of typical relational contracting counterparties, see Amy J. Schmitz, Access to Consumer Remedies in the Squeaky Wheel System, 39 Pepperdine L Rev 279, 290-300 (2012) (describing the characteristics of consumers); Bernstein, 99 Mich L Rev at 1762-64 (cited in note 53) (describing relational contract relationships in the cotton industry); Lisa Bernstein, Opting Out of the Legal System: Extralegal Contractual Relations in the Diamond Industry, 21 J Legal Stud 115, 130-32 (1992) (same, in the diamond industry); Macaulay, 28 Am Sociological Rev at 65-67 (cited in note 53).

274 See Bernstein, $21 \mathrm{~J}$ Legal Stud at 140 (cited in note 273) (explaining that reputational bonds are generally effective only in homogeneous groups).

275 For more on the role of enforceability (however defined), see Andrew A. Schwartz, Consumer Contract Exchanges and the Problem of Adhesion, 28 Yale J Reg 313, 324-26 (2011) (arguing that legal enforceability is necessary for a contract to have value and that relational contracts are a viable alternative to legal enforceability only if the parties have a personal, long-term relationship).

276 See Ronald J. Mann and Travis Siebeneicher, Just One Click: The Reality of Internet Retail Contracting, 108 Colum L Rev 984, 1011 (2008) ("Although many of the customers are repeat customers, there is by definition almost no opportunity online for the kind of personal interaction that characterizes relational contracting as it is commonly understood."); F. Scott Kieff, Coordination, Property, and Intellectual Property: An Unconventional Approach to Anticompetitive Effects and Downstream Access, 56 Emory L J 327, 356 (2006) (noting that relational contracting is effective "within homogeneous communities").

277 Aditi Bagchi, Parallel Contract, 75 U Pitt L Rev 139, 142 (2013). 
Thus, Etsy, Tumblr, and Kickstarter (and to a lesser extent, Airbnb) may illustrate a genuinely novel contracting form. Their end-user contracting framework is designed to build on an existing relationship and generate trust by the users toward the firm and toward each other. But it does so on a massive scale through terms of use that are embedded into the firm's existing trade dress. Users can participate in the terms' creation, or at least are invited to do so in a way that makes them feel included. But the terms themselves are nonnegotiable and are enforced against the users not by the threat of suit but by exclusion from the market. The case study contracts aren't just accomplishing the ordinary goals of conveying information and setting up rules. They are doing that, but they are also marketing materials, demonstrating values the firms think are useful - that is, we're progressive, nonconformist, funny, hip, young, and above all, not evil.

\section{The Future of Contract Regulation (and Regulation by Contract)}

Authors selling normative prescriptions standing on a limited number of case studies should be distrusted. This Section, cognizant of the strength of the evidence on which it rests, will make two observations and then pose a series of hopefully orientating questions about the nature of future research into the functioning of mass contracts.

First, an implicit premise of this Article is that contract theorists should treat precatory terms and exculpatory terms as distinct objects of study. To date, they have not, all but ignoring precatory terms.278 But if contract (particularly consumer contract) theory is to become realistic, we ought to revisit our accounts of contracting to deal with the fact that many terms in adhesive mass-market contracts purport to extend the performance obligation beyond the point of purchase, and yet are obviously not intended to have legal force.

The evidence I adduce tends to discredit accounts that deem these terms to be inert as a product of a monopolistic bar's failure to innovate. Precatory terms do have multiple functions. The most obvious one-options to enable the firm to manage unruly users-is underdeveloped in the literature, which generally focuses on bad behavior by firms, not their customers. But they

278 Selection plays a role here-only exculpatory terms are typically tested in court, leading to decisions that are the grist for law review treatments. 
also, it seems, can help to build firms' brands and can even help the firms to coordinate user behavior and keep users engaged with the platform. The degree to which the latter functions have wide appeal is highly debatable: this Article simply can tell us that some firms, some of the time, justify costly innovation with precisely this claim to utility.

Second, the case studies suggest that scholars might have missed a potential way that disclosure could be made functional. When trying to solve the problem of aversive, unread, exculpatory terms, many modern thinkers have pushed a solution designed to remedy cognitive problems of information overload.279 For example, some advocate for smart disclosure mandates like warning boxes that stand out with unexpected terms, ${ }^{280}$ or graphical warning labels for terms that are particularly unfair.281 The consumer contract problem is conceived of as a problem of mandating the precisely right disclosures because it is assumed that firms always lack incentives to encourage readership.

The examples of success that I provide here suggest the possible futility of even sophisticated disclosure regimes. ${ }^{282}$ Each of the case studies suggests that terms exhort when they are trusted, built from the ground up with buy-in from the firm's users, and fit with the brand. Or to put it differently, the case studies might be thought of as a market test of the question of how to encourage mass readership. Firms selected brands over labels. Scholars might follow this path (through experiments or otherwise) to see if informality and brand alignment increase comprehension and use of terms.

This naturally leads to some potential research questions about relational contracts of adhesion. There is much we do not know. Are Etsy's house rules better than eBay's? Are Airbnb's better than Hyatt's? Tumblr's than Instagram's? In what way?

279 See, for example, Jonathan A. Obar and Anne Oeldorf-Hirsh, The Biggest Lie on the Internet: Ignoring the Privacy Policies and Terms of Service Policies of Social Networking Services *23 (TPRC Working Paper, Sept 23, 2017), archived at http:// perma.cc/K9KL-UGEH (finding that readers ignored terms when joining a networking site, in part because of "information overload").

280 See Ayres and Schwartz, 66 Stan L Rev at 553 (cited in note 1).

281 For a skeptical discussion, see Omri Ben-Shahar and Carl E. Schneider, More than You Wanted to Know: The Failure of Mandated Disclosure 135-37 (Princeton 2014) (discussing the failure of nutrition labels and people's inability to understand them).

282 See id at 125 ("Simplicity . . . is usually in tension with full disclosure."). 
These are questions that are difficult to get a handle on. ${ }^{283}$ As Professor Calo and Alex Rosenblat have pointed out, we should be cautious before taking the sharing economy firms at their mission statements. ${ }^{284}$ These firms are motivated to extract value from users in whatever ways are at hand: contracts that give with one hand may take away with another in ways invisible to external observers. I can't conclusively determine whether the contracts I identify, which are in some ways much friendlier to users than is the norm, are being undermined through conduct behind the scenes. Have they created a real relationship of cooperation and trust (the firms' story) or merely perpetuated a narrative of trust that enables the firms to profit from customers who have mistakenly concluded that they are merchants rather than the products being sold? This is a question worth further detailed study. ${ }^{285}$

Relatedly, the theory I lay out is highly reliant on stories told by particular firms' lawyers, who wrote the contracts in question, spent time justifying them to other stakeholders, and clearly have an interest in being portrayed as both progressive and innovative. Indeed, I gave the lawyers permission to read and edit their quoted comments before this Article's circulation, and any direct quotes they believed reflected badly on them would not have survived such an inquiry. It is interesting, and perhaps telling, that none of the general counsel I spoke to provided hard data about readership rates or designed systems to rigorously evaluate their modified terms' behavioral effects. ${ }^{286}$ That is not to say that the lawyers I spoke to were deceiving (me or themselves). Rather, to

283 Similarly difficult to determine is how courts ought to fold the design features of such contracts into their explicit terms. See Hartzog, 60 Am U L Rev at 1653-61 (cited in note 24) (arguing for courts to consider online contract terms' design when evaluating them).

284 Calo and Rosenblat, 117 Colum L Rev at 1627-28 (cited in note 8) ("The sharing economy seems poised to do a great deal of taking-extracting more and more value from participants while continuing to enjoy the veneer of a disruptive, socially minded enterprise.").

285 See generally, for example, Mark Fenster, Coolhunting the Law, 12 Harv Negotiation L Rev 157 (2007) (analyzing lawyers' roles in crafting companies' brands).

286 Even if data on readership rates were not illuminating, certainly such firms could (and maybe do) have information about customer service load. See, for example, Mathew Patterson, How Top Customer Service Teams Measure Performance (HelpScout), archived at http://perma.cc/AU98-VQHL (describing a tool that provides real-time metrics on customer service activity). 
the extent that part of the story I tell is one of contract as marketing, we ought to be wary of taking more grand claims of behavioral influence at face value.

If we were to become convinced that relational contracts of adhesion were influencing users to read and use their contracts, further qualitative and quantitative study might suggest the limits of users' acquiescence to the regulatory regime: Is buy-in stronger with those who make more money on the site? Who have been there longer? Who commented on the terms in their drafting? The apparent reticence of firms like Airbnb to ask probing questions of their users suggests that not all firms will be equally able to affect behavior or want to learn about it. Similarly, to what extent is success here a product of rarity: If all firms' terms looked as cute as Etsy's, would users become numb?

Obviously, only a few firms have user terms that look anything like the ones I've studied. Why is that? Are relational contracts of adhesion limited to circumstances in which users are also merchants? To firms pressed on the problem when they were small enough to care but big enough to invest? To firms born in New York City? Near Union Square? A research project that looked at those firms that did not innovate, though they had the opportunity to do so, might help to provide clarity on these issues.

\section{CONCLUSION}

Channeling user behavior is one of the mission-critical tasks in the sharing economy. Firms have spent enormous energy on that project, mostly in the form of behavioral nudges ${ }^{287}$ and software like Digital Rights Management. ${ }^{288}$ Technological evangelists are even starting to promise that "smart contracts" based on decentralized ledger technology - a set of tools and protocols that exchange and verify data without centralized intermediariescan solve certain problems in the consumer space. ${ }^{289}$

287 See Calo and Rosenblat, 117 Colum L Rev at 1650-54 (cited in note 8) (explaining how firms can "nudge" consumers to behave in ways beneficial to the firm).

288 Digital rights management (DRM) allows parties to control access to information and to track and monitor content. Rebecca Wexler, The Private Life of DRM: Lessons on Privacy from the Copyright Enforcement Debates, 17 Yale J L \& Tech 368, 373 (2015). In Europe, the Pirate Party system was built on opposition to DRM technologies. See id at 379-81 (describing the Pirate Party's foundational orientation against DRM restrictions); Rub, 103 Va L Rev at 1215-16 (cited in note 13) (exploring DRM as an alternative to contractual control).

289 See Alexander Savalyev, Contract Law 2.0: Smart Contracts as the Beginning of the End of Classic Contracts Law, 26 Info \& Communications Tech L 116, 123 (2017) ("But 
Notwithstanding these sophisticated techniques, firms continue to deploy benumbing terms of use to users who do not read them. ${ }^{290}$ Those terms continue to purport to govern user behavior. Their regulations can be bizarre; for example, the fine print "tells" you not to drive Beyoncé home from a concert in your Zipcar or trade on insider tips when registering for your honeymoon. ${ }^{291}$ Indeed, so odd does the project of governing the public with contract terms seem that no one has written carefully about it. Precatory and executory terms are seen as part of the same story of uncreative exploitation.

It's dangerous to generalize from case studies, let alone ones that valorize their subjects. This Article can merely claim that not all mass-market contracts look the same, and they might not function identically, either. Some might be changing user behavior by drawing on practices (of reciprocity, informality, and trust) traditionally sourced to individualized, negotiated, off-line deals. The challenge going forward is to understand better what role the law and legal institutions play in creating innovation around such relational contracts of adhesion.

in contrast to classic contract where trust is put in the personality of the other party to the contract, in Smart contracts such trust is put in the computer algorithm standing behind the agreement."); Joshua Fairfield, Smart Contracts, Bitcoin Bots, and Consumer Protection, 71 Wash \& Lee L Rev Online 35, 38 (2014) (defining smart contracts as "automated programs that transfer digital assets").

290 Indeed, some firms may be attempting to discriminate in favor of the rare borrowers who read terms, who (at least according to press reports) may be better credit risks. See Steve Lohr, Banking Start-Ups Adopt New Tools for Lending (NY Times, Jan 18, 2015), online at http://www.nytimes.com/2015/01/19/technology/banking-start-ups-adopt -new-tools-for-lending.html (visited Apr 1, 2018) (Perma archive unavailable) (describing Earnest, a lending firm that generates risk profiles for borrowers based in part on how long they spend reading the online terms and conditions of the loan).

291 Users of Honeyfund, a honeymoon crowdfunding site, are prohibited from "posting, providing, transmitting, or otherwise making available any information which violates regulations promulgated by the Securities and Exchange Commission, or that of any securities exchange, such as the New York Stock Exchange." Terms of Use (Honeyfund, Nov 11, 2012), archived at http://perma.cc/MRP3-9A3S. 